\title{
Empirical estimation of the annual range of monthly-mean temperatures
}

\author{
B. Geerts \\ With 21 Figures \\ Received August 23, 2001; accepted June 17, 2002 \\ Published online • • C Springer-Verlag 2002
}

\begin{abstract}
Summary
This is a sequel to a study of the empirical estimation of the annual-mean temperature at any location on land, using only geographical information - latitude, elevation, distance from the nearer ocean shore at the same latitude - and coastal sea-surface temperature. Here long-term mean station data and NCAR/NCEP (National Center for Atmospheric Research/National Centers for Environmental Prediction) global re-analysis data are used to describe and estimate spatial patterns of annual range of monthlymean temperatures. The two key influences on annual range are the latitude and the distance from the upwind shore. Secondary factors include mountain barriers, shape of the local topography, elevation, and vicinity to large bodies of water. An empirical relationship is derived, based on the two key factors alone, assuming zonal winds and adjustments for the effects of mountain barriers and for the proximity to a sea to the north or south. An independent test of this relationship yields errors around $1.0 \mathrm{~K}$. The range estimates yield January and July average temperatures when combined with annual-mean temperatures. Such estimates also carry an uncertainty of about $1.0 \mathrm{~K}$. The procedure can be inverted, i.e. knowledge of the annual mean and range can be used to infer location.
\end{abstract}

\section{Introduction}

There are several reasons for understanding geographical factors affecting the climate of a place, and they were considered in a previous paper (Linacre and Geerts, 2002, referred to as LG02). That dealt with estimating the annual-mean temperature for a given latitude, elevation, distance inland from the coast, and coastal sea surface temperature (SST). The most accurate method of annual-mean temperature estimation involved average absolute errors of $0.7 \mathrm{~K}$. Here we extend that study to allow estimation of the average temperatures of the warmest and coldest months, from similar geographical information.

The true ATR (annual temperature range) is here defined as the long-term mean difference between the monthly-mean temperatures of the warmest and coldest months. This range does not always equal the apparent ATR, i.e. the absolute difference between the January and July mean temperatures.

The ATR is a key climate parameter and a determinant of ecosystem variability. Several paleoclimatological studies, for instance, have attempted to reconstruct ATR variations, using proxy records (e.g. Andreasson and Schmitz, 1996, 2000) or general circulation models (GCMs) (e.g. Renssen and Isarin, 1997), as a way of characterizing paleo-environments. Warm-season temperatures vary much less, geographically, than do cold-season temperatures. For instance, Miami is $43 \mathrm{~K}$ warmer in January than Fairbanks, in Alaska, but only $11 \mathrm{~K}$ warmer in July. Ecosystems are quite sensitive to the minimum temperature. The definition of the U.S. 
Department of Agriculture Plant Hardiness zones, for instance, is based merely on the lowest temperature one can expect in any year at a given location (Cathey, 1990).

The ATR varies from year to year. Generally the standard deviation is larger at places where the ATR itself is larger. Interannual variations of ATR have long been studied (e.g. Conrad, 1940) and have been related to such teleconnection patterns as the El Niño Southern Oscillation (e.g. Jones, 1999), or the Pacific North American pattern (Konard, 1998). There may also be a longterm trend in ATR. GCMs indicate that increased atmospheric concentrations of greenhouse gases will warm the coldest month more than the warmest month, especially at higher latitudes, in other words the ATR should decline, as has been observed for the diurnal range (Mearns et al., 1995; Watterson, 1997). In fact this reduction in ATR has been observed in some regions, such as Alaska (Stafford et al., 2000). Therefore it is important to understand the ATR and monitor historical changes. Here we deal with the climatological ATR, and ignore internannual and long-term variations.

Factors influencing the ATR on land include distance from the upwind shore and latitude. For instance, Linacre (1969) related the ATR to the distance inland and the annual range of monthly-mean solar radiation, which is a function of latitude. Other factors include the effects of mountain ridges, which inhibit low-level advection and dehydrate an airmass that does transgress. (A larger ATR tends to occur in drier air because of the paucity of clouds and because water vapor is a greenhouse gas.) The shape of the local terrain, the elevation, the vicinity to inland seas, land use and land cover, and the annual range of the SST off the upwind shore also may influence ATR. We shall consider those, except the effects of land use and urbanization, which are addressed separately (Geerts, 2002a).

This paper illustrates how these factors affect ATR, and establishes and tests an empirical relationship between basic geographic patterns and ATR. Some of the data that we use come from the book by Linacre and Geerts (1997), hereafter referred to as LG97, and from Linacre (1992) i.e. L92. The main resources have been a) the International Station Meteorological Climate Summary, version 4.0 , issued on a CD-ROM by the US National Climate Data Center in 1996 (referred to as ISMCS), and b) the NCAR/NCEP global re-analysis of weather station, buoy and satellite data between 1968-96 (Kalnay et al., 1996) (referred to as NNGR). The NNGR resolution is 2.5 degrees and 12 hours. Monthly-mean NNGR data can be accessed at http://www.cdc. noaa.gov/.

First it is shown that latitude alone explains only part of the observed ATR variation. Next the annual range of coastal SST is related to the range of surface-air temperatures at coastal stations, which demonstrates the importance of upwind distance from shore. The latter is examined further in Section 3. Section 4 addresses the influence of topography. A simple method to deduce ATR from key geographic factors is tested for 50 places, and it is combined with an estimation of annual-mean temperature (LG02) to derive January and July mean temperatures. Finally, the inverse process is demonstrated, i.e. the deduction of geographic information from observed annual mean and range.

\section{Effect of latitude on annual temperature range}

\subsection{Global perspective}

The latitudinal variation of the true ATR $R_{t}$ is seen in Fig. 1. The true range $R_{t}$ was calculated for each grid point of the NNGR data, before it was zonally averaged. The true ATR is small in the equatorial belt, and it generally increases with latitude. It can be seen that $\mathrm{R}_{\mathrm{t}}$ varies differently in the two hemispheres, being less in the south, especially between $30-60^{\circ} \mathrm{S}$, where there is more ocean. In fact at higher latitudes the ATR correlates well with the areal fraction of land surface at that latitude (LG97 p. 62).

The Arctic region is an exception, consisting largely of ocean, but this ocean is largely covered by ice, so the winters can be quite cold, since surface heat fluxes from sea ice are not much larger than those over land. Without the ice the Arctic would be more humid, supporting more clouds, implying a smaller ATR. There is some decrease in ATR north of $\sim 70^{\circ} \mathrm{N}$, because the area of Arctic sea ice in late summer is only about $26 \%$ less than in late winter, so the Artic Sea remains 


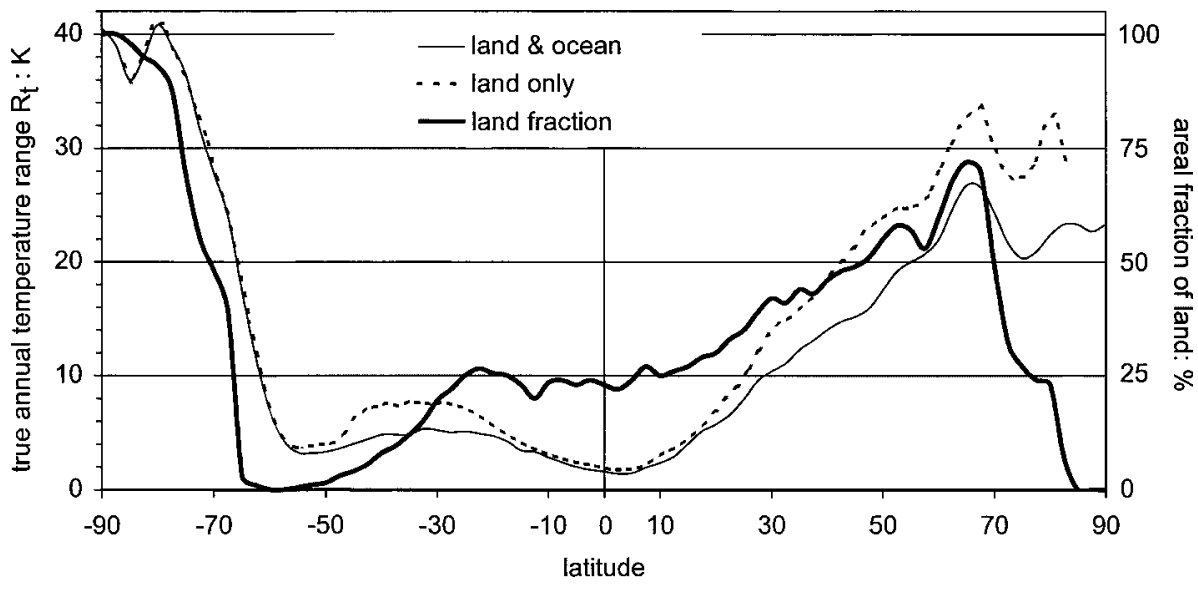

Fig. 1. Variation with latitude of the zonal means of the true ATR $R_{t}$ for the entire globe (thin solid line) and for continents alone (dashed line), based on gridded NNGR surface-air temperatures. Also showing is the percent of land surface (bold solid line). Negative latitudes refer to the southern hemisphere considerably cooler than the surrounding boreal continents in summer.

There is some asymmetry of extra-terrestrial radiation $\left(\mathrm{Q}_{\mathrm{x}}\right)$ about the equator. More $\mathrm{Q}_{\mathrm{x}}$ is received in the southern summer than in the northern summer, because of the Earth's present orbital characteristics: the perihelion is nearly coincident with the northern winter solstice. Therefore there is more wintertime $\mathrm{Q}_{\mathrm{x}}$ in the north (e.g. $160 \mathrm{~W} \mathrm{~m}^{-2}$ in December at $40^{\circ} \mathrm{N}$ ) than in the south (e.g. $149 \mathrm{~W} \mathrm{~m}^{-2}$ in June at $40^{\circ} \mathrm{S}$ ). On the other hand, $\mathrm{Q}_{\mathrm{x}}=502 \mathrm{~W} \mathrm{~m}^{-2}$ in December at $40^{\circ} \mathrm{S}$, but $\mathrm{Q}_{\mathrm{x}}=476 \mathrm{~W} \mathrm{~m}^{-2}$ in June at $40^{\circ} \mathrm{N}$ (L92, p. 323). As a result, the latitude of the least annual range of $\mathrm{Q}_{\mathrm{x}}$ is not the equator but $4^{\circ} \mathrm{N}$ (Linacre, 1969), and this also applies to the ATR $R_{t}$ (Fig. 1).

This study focuses on apparent range $R_{j}$, however $R_{j}$ is not always the same as true range $R_{t}$. The extreme months are almost always January and July at middle and high latitudes. A notable exception is found along the coast of northern California, where northerly winds in summer induce upwelling and low SST values. The warmest month is September in San Francisco, for instance. Other places with coastal upwelling and anomalously low SSTs, such as the coastal areas of SW Africa and central Chile, do not experience such a lag, because the wind does not shift seasonally and upwelling continues year-round. The apparent range $R_{j}$ is often less than $R_{t}$ at low latitudes, especially in the northern hemisphere. The warmest month occurs in spring in areas affected by zenithal rains or monsoons. For instance, May is the warmest month in much of India between $18-28^{\circ} \mathrm{N}$.

The difference between the two ranges $\left[R_{t}-R_{j}\right]$ will be called the 'ATR adjustment' $\mathrm{A}$. Its variation with latitude is seen in Fig. 2, following a procedure like that for Fig. 1. The ATR adjustment is largest around $10-15^{\circ} \mathrm{N}$, where the zenithal rain period tends to be well-defined. This

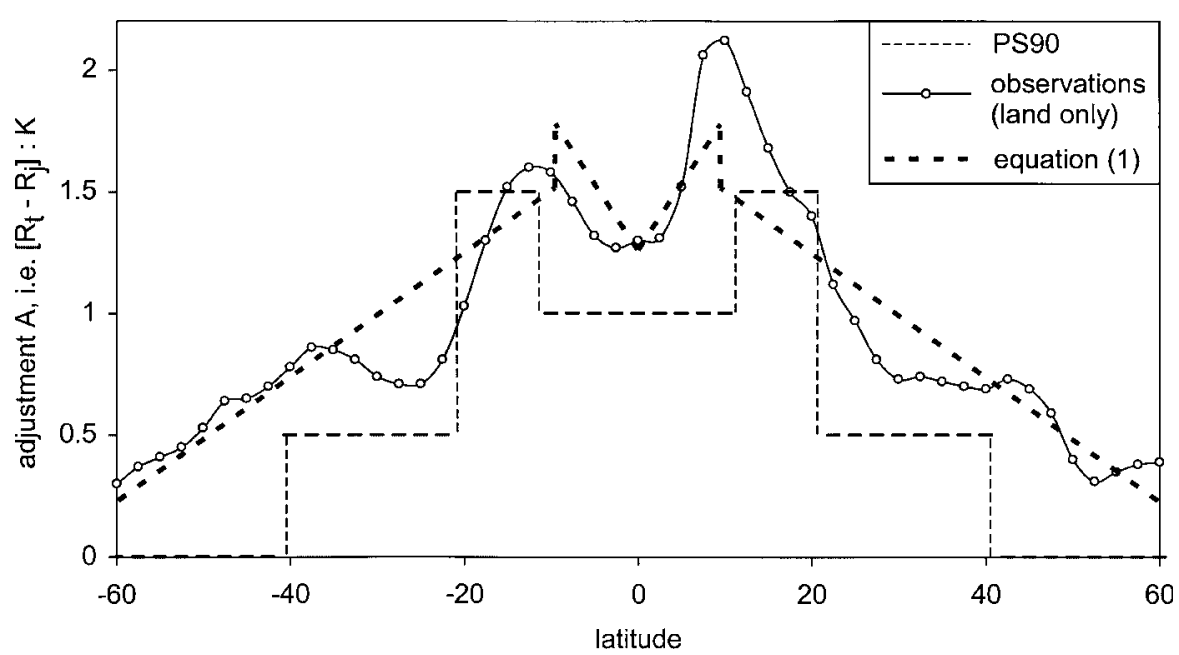

Fig. 2. The zonal-mean adjustment from the apparent range $R_{j}$ to the true range $R_{t}$, i.e. the difference $\left[R_{t}-R_{j}\right]$. The 'observations' are based on NNGR, for continental areas only. The thin, dashed line indicates adjustment values as suggested by Pearce and Smith (1990), PS90, and the bold dashed line represents Eq. (1) 
is reflected in the ATR adjustment values suggested by Pearce and Smith (1990) (Fig. 2). A better approximation to the curve of observations of $\left[R_{t}-R_{j}\right]$ over land is shown in Fig. 2 and is given by the following: (Note that as in LG97 differences of temperature are expressed in Kelvin, whereas temperatures themselves are expressed in degrees Celsius.)

for $|\mathrm{L}|<10, \quad \mathrm{~A}=1.2+0.063 \mathrm{~L} \mathrm{~K}$

for $10<|\mathrm{L}|<60, \quad \mathrm{~A}=1.8-0.027 \mathrm{LK}$

The ATR adjustment actually is asymmetric about the equator (Fig. 2), partly because of the Earth's orbital conditions, partly because there is more land (and hence stronger monsoons) between $20-30^{\circ} \mathrm{N}$ than between $20-30^{\circ} \mathrm{S}$ (Fig. 1). But this asymmetry will be ignored.

The global variation of the true range $\mathrm{R}_{\mathrm{t}}$ (Fig. 3) shows that the two dominant factors affecting ATR are:

(a) latitude - the ATR increases with latitude;

(b) distance inland - as an example, compare the range of $39 \mathrm{~K}$ at Ulaan Baatar in Mongolia $(9000 \mathrm{~km}$ inland from the Atlantic Ocean at $48^{\circ} \mathrm{N}$ ), to a value of $6.7 \mathrm{~K}$ at San Pedro, at the same latitude south in Chile (LG97, pp. 62 \& 220). The ATR near east coasts of the northern continents at mid-latitudes is larger than near west coasts. As a result, the ATR contours (Fig. 3) produce in a distorted image of Asia and North America. In areas without north-south mountain chains, the range steadily increases inland from the upwind coast, as in Eurasia. The same applies inland from any coast where winds are weak or seasonally variable, as in much of Australia.

The following two factors appear also to be significant (Fig. 3):

(c) blocking terrain - the ATR gradient is large in areas with one or more high mountain ranges that block the penetration of marine air, for instance in western North America or southern South America;

(d) inland seas - these appreciably mitigate the ATR in adjacent (downwind) coastal areas, and this effect increases with the sea's size. For instance, the ATR is anomalously small over the Mediterranean, Black, Caspian and Baltic Seas (Fig. 3). Even the Great Lakes have an influence, although the impact of the Hudson Bay is small, notwithstanding its size, presumably because it largely freezes in winter.

The effect of elevation is not obvious in Fig. 3. For instance the ATR is not unusually low or high over the Tibetan highland, where it gradually increases from south to north. In short, Fig. 3 indicates that factors $(\mathrm{a}-\mathrm{b})$ need to be considered

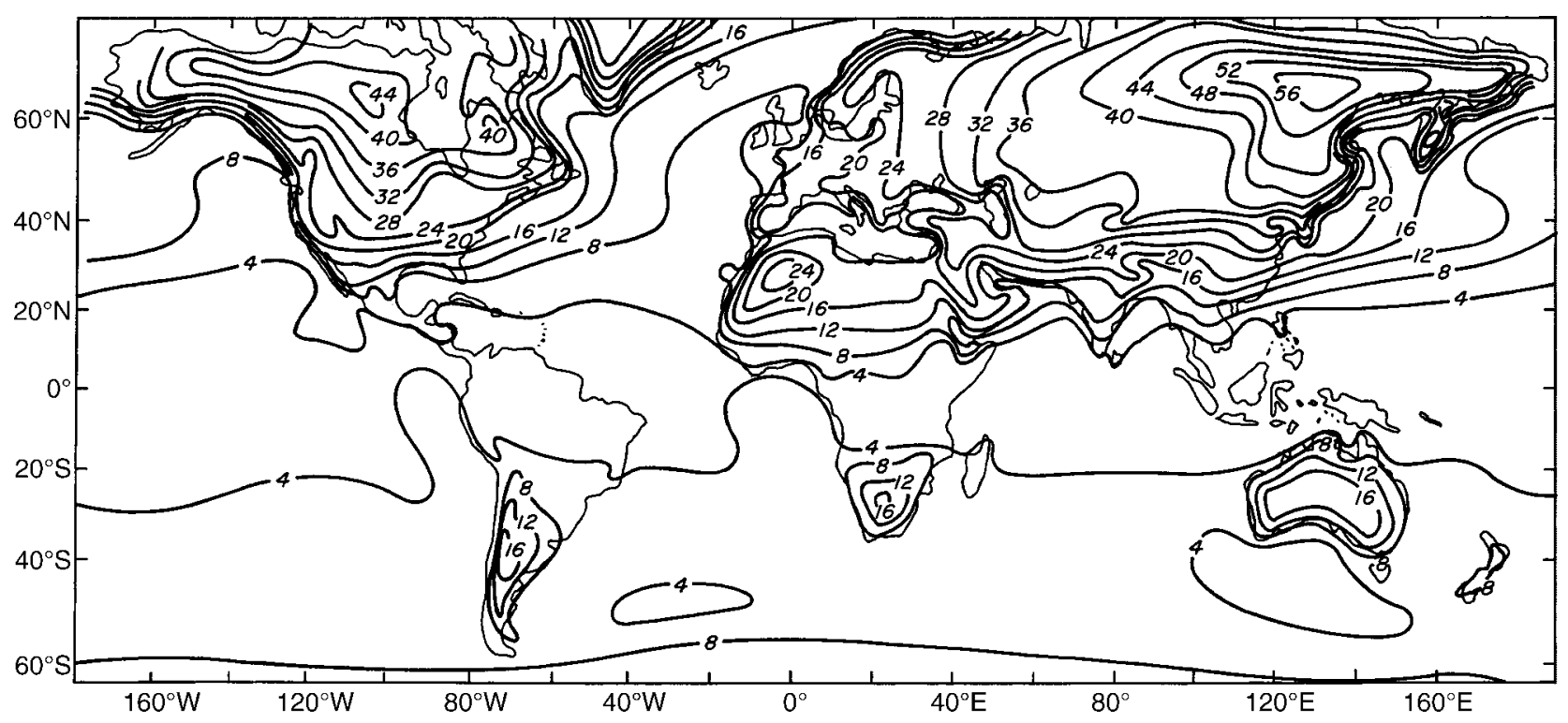

Fig. 3. Global distribution of the true ATR $R_{t}$ (after Wallace and Hobbs, 1977; p. 349). The coastlines are shown by thin contours 


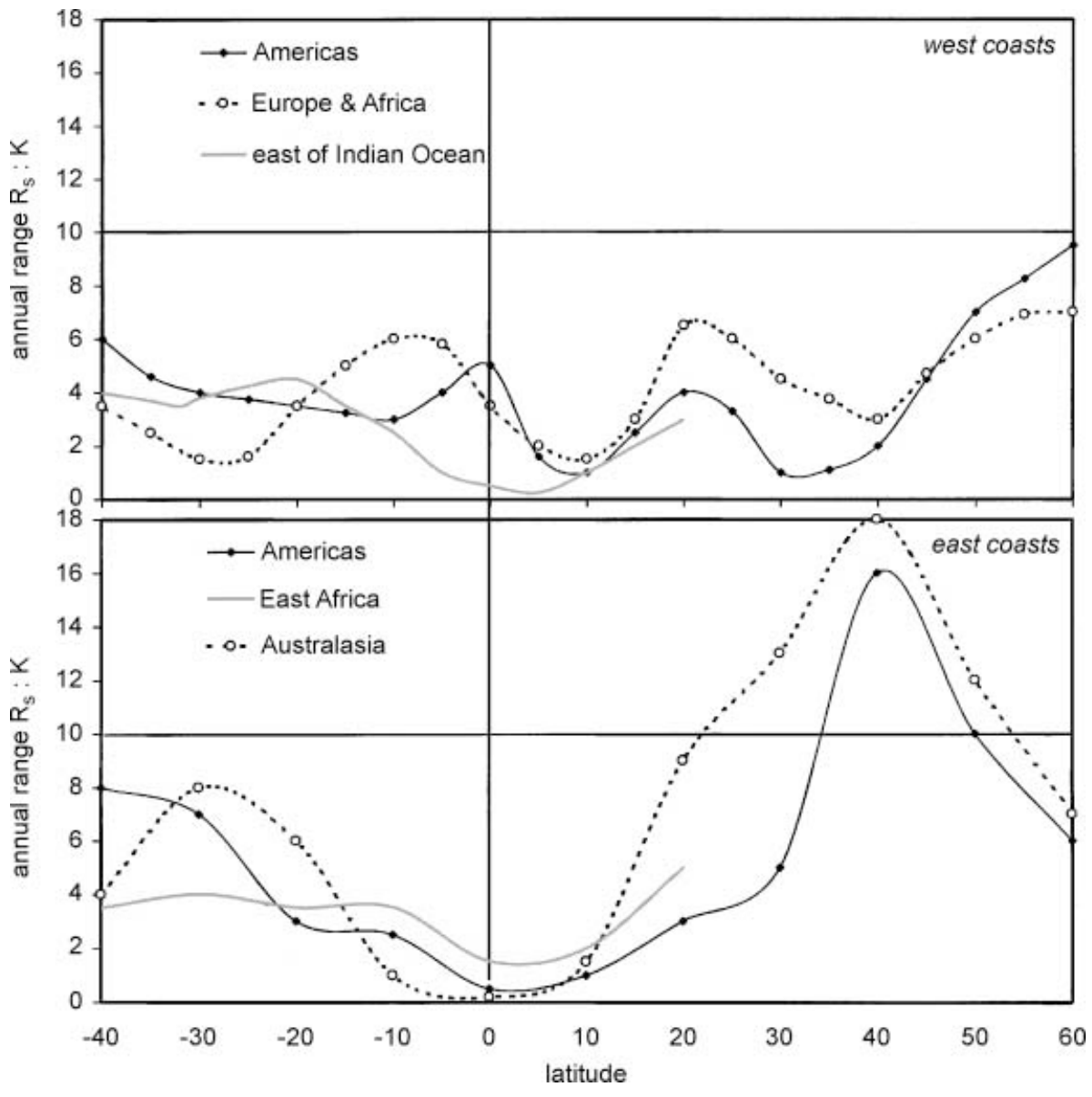

Fig. 4. The variation with latitude of the annual range $R_{s}$ of mean coastal SST in August and February, according to whether east or west coasts of various continents (Sverdrup et al., 1946; LG97, p. 221) first, and that these need to be isolated to understand the effects of $(\mathrm{c}-\mathrm{d})$ on ATR.

\subsection{Meridional gradient}

Both Fig. 4 in Legates and Willmott (1990) and Fig. 3 herewith indicate that the annual range of surface air temperature over the oceans, $R_{\text {to }}$ increases with latitude, most rapidly at mid-latitude western ocean margins. The best linear fit of $\mathrm{R}_{\mathrm{to}}$ (based on the NNGR) with latitude $\mathrm{L}$ (degrees, either north or south) between $60^{\circ} \mathrm{S}-$ $60^{\circ} \mathrm{N}$ implies a gradient of $0.14 \mathrm{~K} /{ }^{\circ}$ :

$\mathrm{R}_{\mathrm{to}}=1.4 *(1+\mathrm{L} / 10) \mathrm{K}$

The meridional gradient of ATR is larger over land (Fig. 3). The NNGR data suggest that the ATR gradient over land is fairly constant between $5-65^{\circ} \mathrm{N}$, at about $0.53 \mathrm{~K} /{ }^{\circ}$ (Fig. 1). This is consistent with an ATR gradient of $0.56 \mathrm{~K} /{ }^{\circ}$ for five stations at $90^{\circ} \mathrm{W}$ in North America, and a value of $0.65 \mathrm{~K} /{ }^{\circ}$ for five stations at $90^{\circ} \mathrm{E}$ in
East Asia. Across Europe and western North America the ATR gradient is smaller, at about $0.4 \mathrm{~K} /{ }^{\circ}$ (Pearce and Smith, 1990).

The ATR gradient is much smaller in the southern hemisphere (Fig. 1), and is negative between $40-55^{\circ} \mathrm{S}$. But most 'land gridpoints' included in Fig. 1 between $35-60^{\circ} \mathrm{S}$ represent coastal or island locations, i.e. mainly ocean conditions. The gradient of apparent ATR is around $0.37 \mathrm{~K} /{ }^{\circ}$ in South America (LG97, p. 63), while 34 places in Southern Africa yield $0.34 \mathrm{~K} /{ }^{\circ}$ (LG97, p. 370), and ten places in Australia yield $0.25 \mathrm{~K} /{ }^{\circ}$.

In summary, a typical meridional gradient of apparent ATR $R_{j}$ over land is $0.5 \mathrm{~K} /{ }^{\circ}$ in the northern hemisphere and $0.3 \mathrm{~K} /{ }^{\circ}$ in the south. These figures can be used to adjust the observed ATR at places to values at a nearby common latitude.

\subsection{Ranges of coastal sea-surface temperatures}

The annual range of SST at the oceans' edges, $\mathrm{R}_{\mathrm{s}}$, is shown in Fig. 4, assuming that February 


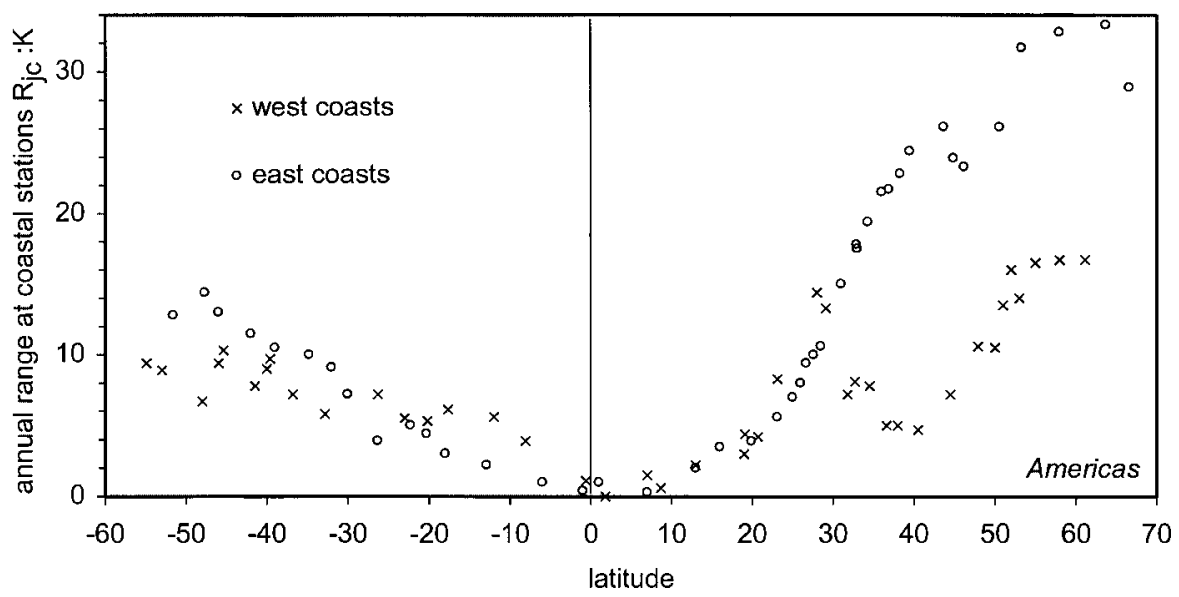

Fig. 5. Effect of latitude on the annual range $R_{j c}$ of screen temperatures at coastal stations in the Americas (based on ISMCS data) and August are the months of highest and lowest monthly-mean SSTs (Reynolds and Smith, 1995). Coastal SST ranges are different from typical annual ranges of air temperature out at sea (Section 2.2). It can be seen that ranges are small on west coasts, averaging about $4 \mathrm{~K}$. They vary irregularly with latitude, being least at $10^{\circ} \mathrm{N}$ and increasing with latitude at about $0.08 \mathrm{~K} /{ }^{\circ}$. The small value of $R_{s}$ around $30-40^{\circ} \mathrm{N}$ is due to the upwelling of cold deep-water off California and northwest Africa. This upwelling occurs mainly or only in summer.

The SST range increases more rapidly with latitude from the equator up to $30^{\circ} \mathrm{S}$ and $40^{\circ} \mathrm{N}$ along east coasts, from 0.2 to $0.4 \mathrm{~K} /{ }^{\circ}$. Westerly air currents, modified by a long fetch over land, blow off the east coasts of Asia and N. America near $40^{\circ} \mathrm{N}$, explaining the large range $\mathrm{R}_{\mathrm{s}}$ off east coasts. But $\mathrm{R}_{\mathrm{s}}$ decreases at higher latitudes. In the northern hemisphere, the decrease is due to the cold Oya Shio and Labrador ocean currents, which are cold in summer and no colder than $0{ }^{\circ} \mathrm{C}$ in winter. In the south, $\mathrm{R}_{\mathrm{s}}$ decreases slightly towards $40^{\circ} \mathrm{S}$ because of the thermal inertia of the vast Antarctic circumpolar current south of Africa and Australia.

In summary, the annual range of the coastal SST is small, and its variation with latitude is irregular, depending on boundary currents and upwelling.

\subsection{The coastal onshore range}

The January/July ATR at weather stations at the coast $\mathrm{R}_{\mathrm{jc}}$ was compiled for 84 weather stations within $10 \mathrm{~km}$ from a coast. Half of these stations are near the Pacific coast of the Americas, the other half near the Atlantic coast (Fig. 5). The ATR is almost zero at $5^{\circ} \mathrm{N}$ but increases poleward from there, faster to the north (where the continent widen with latitude) and less fast to the south (where the east and west coasts converge to a point). The asymmetry between north and south is particularly evident along the east coast, where the ATR increases at $\sim 0.3 \mathrm{~K} /{ }^{\circ}$ in the south but at $\sim 0.6 \mathrm{~K} /{ }^{\circ}$ in the north. The ATR increase along the east coast is most rapid around $30^{\circ} \mathrm{N}$, which is the latitude of the Bermuda high, separating onshore winds to the south from offshore (westerly) winds to the north.

The coastal air temperature range $\mathrm{R}_{\mathrm{jc}}$ is $45 \%$ larger than the SST range $\mathrm{R}_{\mathrm{s}}$ along the west coast, but the variation with latitude is similar. For instance, $R_{\mathrm{jc}}$ and $\mathrm{R}_{\mathrm{s}}$ have the same minimum around $40^{\circ} \mathrm{N}$ along the west coast. In other words the ATR at places near west coasts is strongly affected and damped by the ATR of the offshore waters. On the east coast, $\mathrm{R}_{\mathrm{jc}}$ behaves differently from $\mathrm{R}_{\mathrm{s}}$, especially north of $40^{\circ} \mathrm{N}$, and the ratio of $\mathrm{R}_{\mathrm{jc}}$ to $\mathrm{R}_{\mathrm{s}}$ increases with latitude, from 1.5 at $25^{\circ} \mathrm{N}$ to 5.0 at $60^{\circ} \mathrm{N}$. The wintertime east-coastal air temperatures at $60^{\circ} \mathrm{N}$ are far below $0{ }^{\circ} \mathrm{C}$, and appear decoupled from the adjacent ocean. This decoupling is due to prevailing westerly (offshore) winds. This suggests that the ATR at coastal stations is strongly affected by the prevailing wind direction.

This conclusion is corroborated by the ATR at coastal stations on opposite sides of the northern Atlantic Ocean (Fig. 6). Westerly winds prevail at latitudes above $25^{\circ} \mathrm{N}\left(30^{\circ} \mathrm{N}\right)$ in January on the western (eastern) side of the Atlantic. Winds are 

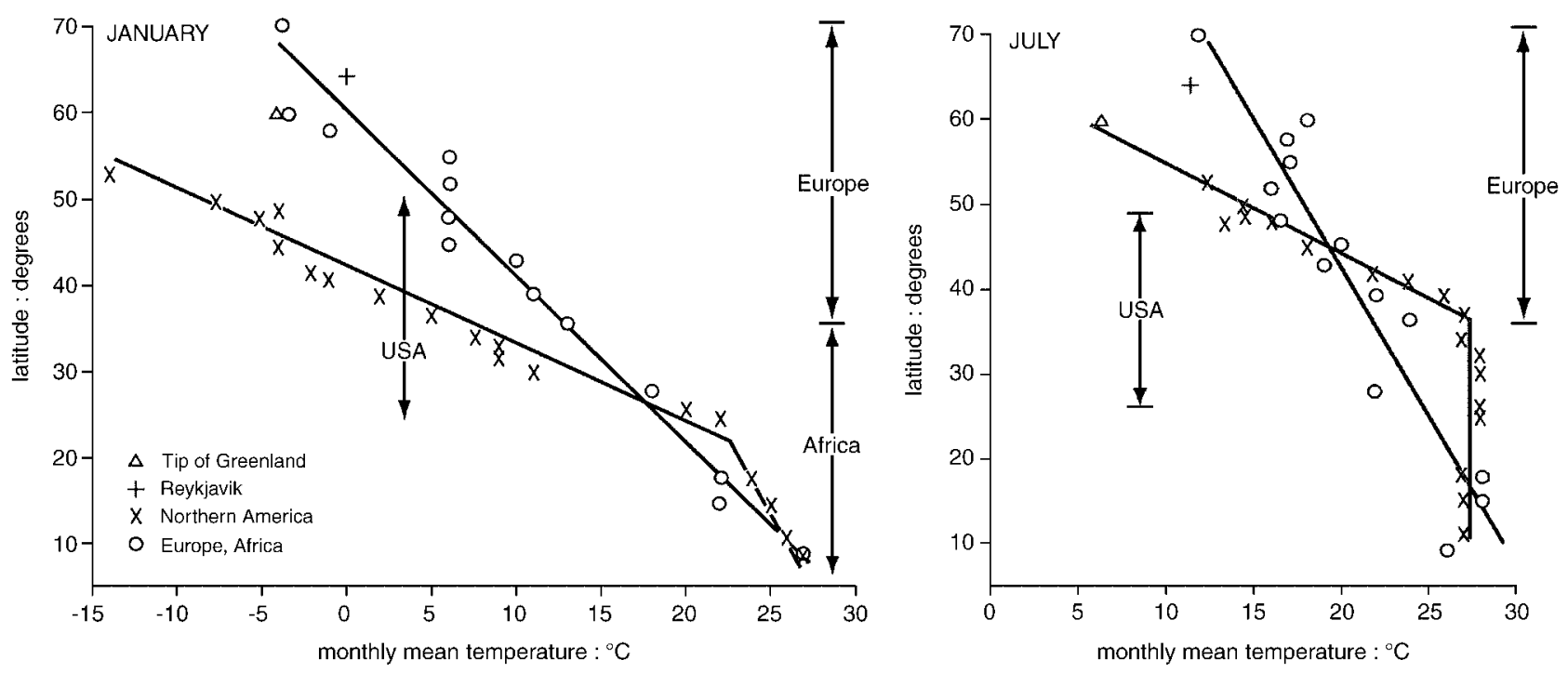

Fig. 6. Mean coastal air temperatures along the edges of the Atlantic Ocean in January (left) and July (right)

primarily easterly at lower latitudes. The separation between easterly and westerly winds is about $5^{\circ}$ further north in July, as the Bermuda high shifts poleward. As a result, North America's eastern seaboard has cold winters but warmer summers than Western Europe between $25-45^{\circ} \mathrm{N}$. At higher latitudes, the cold Labrador Current and the icy coast of Greenland complicate matters, but the ATR remains significantly smaller in Great Britain and Norway than at comparable latitudes on the North American east coast.

In summary, the ATR at coastal stations is larger than the SST range, and is controlled by the ATR of the waters offshore if the prevailing wind is onshore.

\section{Effect of distance inland on annual temperature range}

\subsection{Distance to the nearest shore versus fetch}

The seasonal variation of screen temperature over a land surface is much larger than that over sea because of mixing in the top layer of the ocean, the high thermal capacity of water and more evaporation from the ocean (LG97, p. 62). Therefore a given seasonal variation of incoming solar radiation creates a larger change of air temperature over land than over the ocean. Hence the temperature gradient across a coastline reverses seasonally. In the absence of wind, this gradient would be very large.

The increase of ATR with distance from the sea seen in Fig. 3 is often referred to as 'continentality' (e.g. Barry and Chorley, 1998; p. 35). However, that vague abstraction is sensitive to latitude. The ATR is negligible in both the Amazon and the Congo Basins, yet the characteristics of precipitation systems in the latter are much more 'continental' than in the former (Peterson and Rutledge, 2001). The term 'continentality' is ill-defined and unnecessary; it is better to use the ATR itself as a direct, specific and measurable quantity (L92, p. 319).

The fetch is an estimate of the actual length of the overland track of the wind. It determines the extent to which a maritime airmass is modified towards a thermal equilibrium with the underlying land surface. It might be argued that the reduction of ATR over land depends, not on the distance, but on the time the airmass spends overland, which is inversely proportional to the wind speed. Alone, that implies that the stronger the wind, the larger the reduction of ATR. But that is offset by another factor, the increased rate of sensible heat transfer between surface and air, at higher wind speeds. The result is that the thermal adjustment in approximately proportional to the length of the overland track.

The variation of ATR with distance to the nearest shore in Australia is shown in Fig. 7. The ATR is 'adjusted' for latitude to minimise 


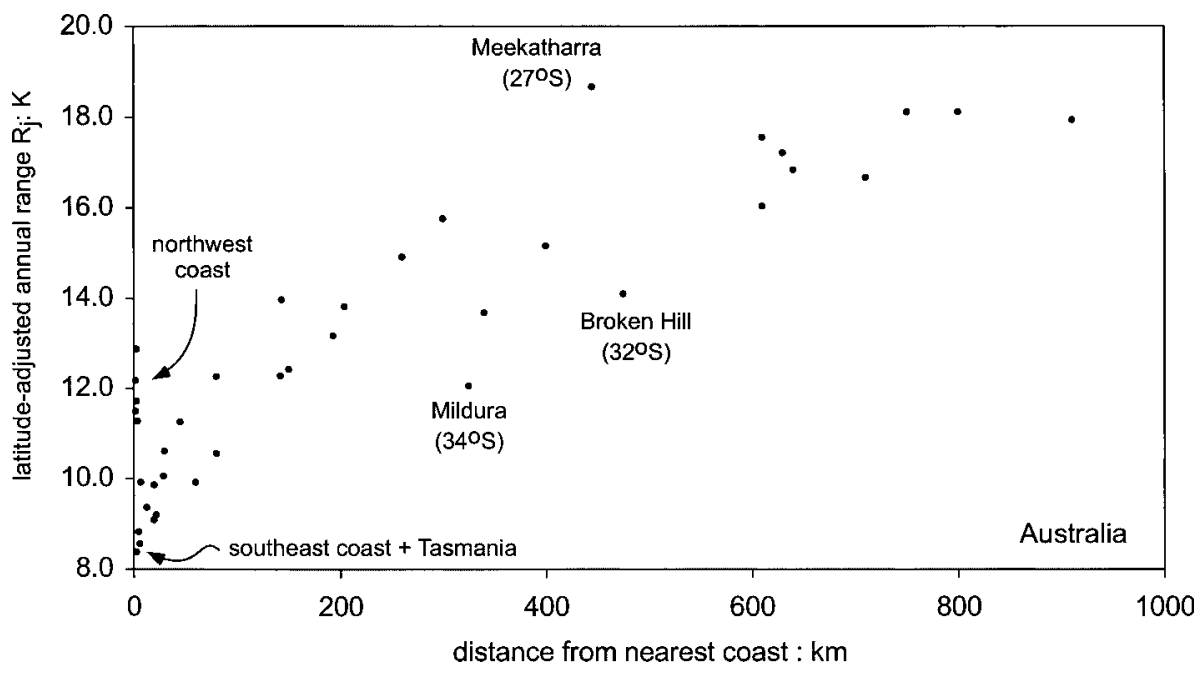

Fig. 7. The variation of ATR $R_{j}$ with distance to the nearest coast in Australia. $R_{j}$ is adjusted $(0.3 \Delta \mathrm{L})$ to a common latitude of $28^{\circ} \mathrm{S}$ the effect of latitude (Section 2.2). The data suggest that the ATR increases rapidly from the coast, but reaches a ceiling about $500 \mathrm{~km}$ from the coast. The rapid change near the coast may be due to sea breezes, which imply lower daytime maxima in summer, and therefore a cooler warmest month. Sea breezes do affect the annual mean temperature in a narrow belt, perhaps $20 \mathrm{~km}$ wide, becoming insignificant around $75 \mathrm{~km}$ inland (LG02). The impact of sea breezes, intermittent onshore flow, and cloudiness on temperature range near a coast are addressed in a separate study (Geerts, 2002b).

Inland places in the southeast, such as Mildura and Broken Hill, have a lower adjusted ATR than places at similar distances inland in the interior and northwest, such as Meekatharra. Australia is largely under the belt of subtropical highs, so the wind is generally weak and variable, but southwesterly winds are more common in the southeast, while easterly winds prevail around Meekatharra. In other words, the typical fetch in the northwest is much longer than the distance to the nearest coast.

\subsection{Wind direction}

Trajectories of air reaching a given location over land vary from day to day and rarely follow a straight zonal path from the adjacent ocean. Yet a clear prevalence of certain wind directions exists in many areas. Zonal winds are generally stronger and more persistent than meridional winds (Fig. 8), but they may vary seasonally.
Therefore, as a first-order approximation, we assume that the distance inland, $d(\mathrm{~km})$, is the zonal distance from the 'upwind' coast, either to the east or to the west, depending on latitude (Table 1). This distance is always less than the average fetch.

Zonal winds reverse direction between seasons in some regions, especially in 'monsoonal' regions (LG97, p. 247) (Fig. 8, Table 1). Most of south Asia is monsoonal. Such areas are commonly accompanied by a notably seasonal variation of rainfall. For example Shanghai's prevailing winds shift between seasons, and its rainfall in July is around three times what it is in January (Pearce and Smith, 1990, p. 221). If the prevailing zonal wind direction varies seasonally, according to Table 1, then distances from both east and west coasts are needed to estimate the ATR. A large value of the distance $d$ is appropriate for Shanghai in January, when surface air generally is advected across Eurasia, but $d$ is small in summer when air reaching Shanghai usually travels across the adjacent East China Sea.

\subsection{Meridional winds}

In some regions the prevailing wind is southerly or northerly, and the meridional component often changes seasonally (Fig. 8). The ATR is enhanced where winds blow mainly poleward in summer and equatorward in winter, for instance in the southeastern USA, where winds tend to be southerly in July and northwesterly and more variable in January. But it is reduced 

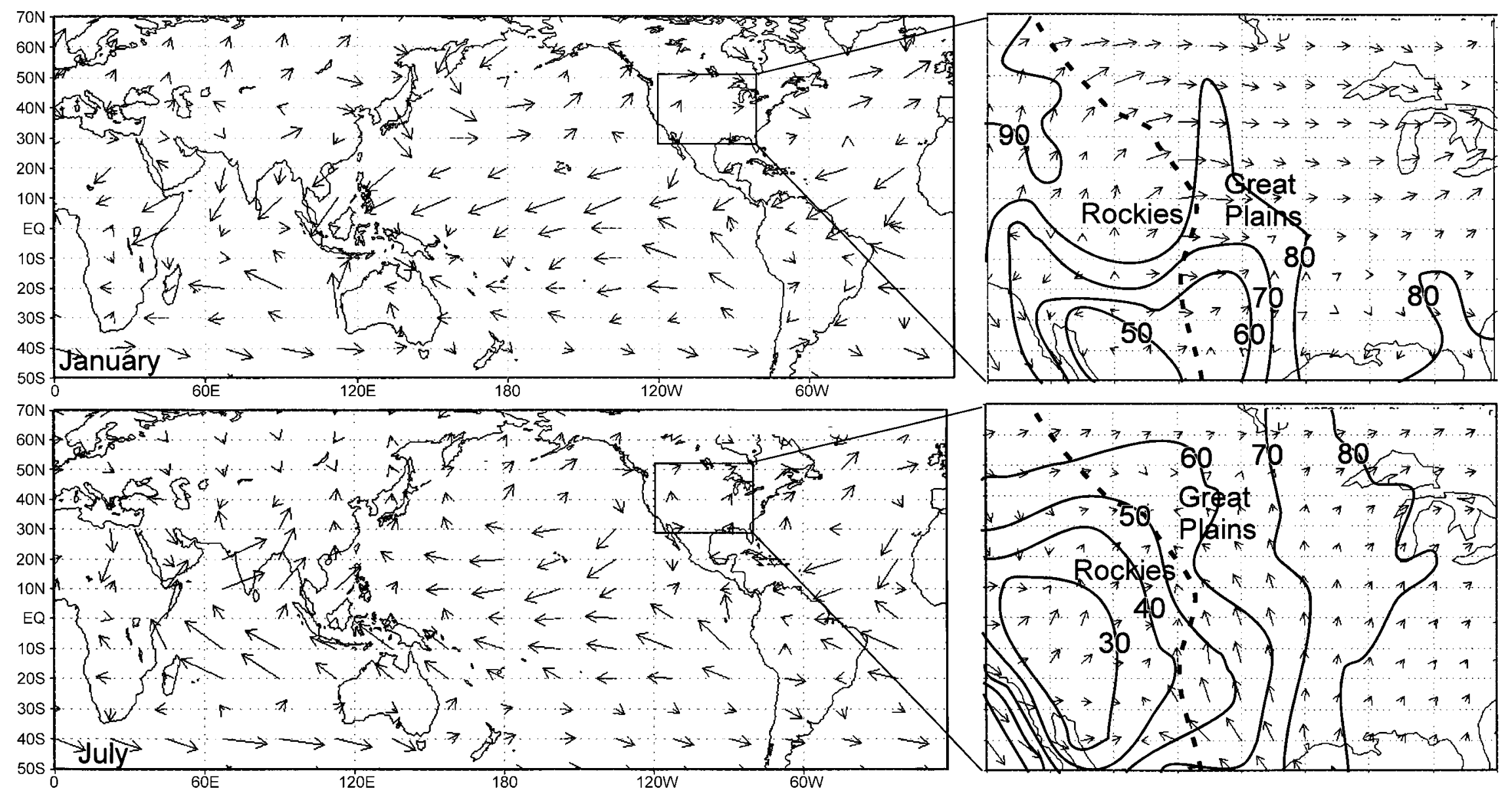

Fig. 8. Mean wind vectors at $10 \mathrm{~m}$ above the surface for January (top) and July (bottom), based on NNGR data. The longest vector shown on the global maps (left) represents $11.2 \mathrm{~m} / \mathrm{s}$. The boxed area over North America is enlarged on the right. The images on the right also show surface relative humidity (\%, solid contours) and the boundary between the Rocky Mountains and the Great Plains (dashed line) 
Table 1. Directions of winds prevailing over various continents, generalised from the wind data plotted in Fig. 8. The $\operatorname{sign}<$ means 'equatorward of', while $>$ means 'poleward of'

\begin{tabular}{|c|c|c|c|}
\hline \multirow[t]{2}{*}{ Continent } & \multirow[t]{2}{*}{ Latitude } & \multicolumn{2}{|c|}{ Wind direction } \\
\hline & & Winter & Summer \\
\hline N. America & $\begin{array}{l}27-65^{\circ} \mathrm{N} \\
17-27^{\circ} \mathrm{N}\end{array}$ & \multicolumn{2}{|c|}{$\begin{array}{l}\text { westerly } \\
\text { easterly }\end{array}$} \\
\hline Central America & $7-17^{\circ} \mathrm{N}$ & easterly & westerly \\
\hline S. America & $\begin{array}{l}7^{\circ} \mathrm{N}-30^{\circ} \mathrm{S}^{\# \mathrm{E}} \\
30-36^{\circ} \mathrm{S}^{\# \mathrm{E}} \\
7^{\circ} \mathrm{N}-36^{\circ} \mathrm{S}^{\# \mathrm{~W}} \\
>36^{\circ} \mathrm{S}\end{array}$ & $\begin{array}{r}\text { ea } \\
\text { westerly } \\
\text { we } \\
\text { we }\end{array}$ & $\begin{array}{l}\text { erly } \\
\text { easterly } \\
\text { erly } \\
\text { erly }\end{array}$ \\
\hline Europe & any & \multicolumn{2}{|c|}{ westerly } \\
\hline Africa & $\begin{array}{l}>31^{\circ} \mathrm{N} \\
20-31^{\circ} \mathrm{N}\end{array}$ & \multicolumn{2}{|c|}{$\begin{array}{l}\text { westerly } \\
\text { easterly }\end{array}$} \\
\hline & $\begin{array}{l}15^{\circ} \mathrm{S}-20^{\circ} \mathrm{N} \\
30-15^{\circ} \mathrm{S}\end{array}$ & \multicolumn{2}{|c|}{ easterly } \\
\hline & $>30^{\circ} \mathrm{S}$ & westerly & easterly \\
\hline Australia & $\begin{array}{l}<17^{\circ} \mathrm{S} \\
17-27^{\circ} \mathrm{S}\end{array}$ & $\begin{array}{r}\text { easterly } \\
\text { ea }\end{array}$ & $\begin{array}{l}\text { westerly } \\
\text { erly }\end{array}$ \\
\hline & $\begin{array}{l}27-36^{\circ} \mathrm{S} \\
>36^{\circ} \mathrm{S}\end{array}$ & westerly & $\begin{array}{l}\text { easterly } \\
\text { erly }\end{array}$ \\
\hline Asia & $41-65^{\circ} \mathrm{N}$ & \multicolumn{2}{|c|}{ westerly } \\
\hline & $\begin{array}{l}30-41^{\circ} \mathrm{N} \\
<30^{\circ} \mathrm{N}\end{array}$ & $\begin{array}{l}\text { westerly } \\
\text { easterly }\end{array}$ & $\begin{array}{l}\text { easterly } \\
\text { westerly }\end{array}$ \\
\hline India & $<20^{\circ} \mathrm{N}$ & \multicolumn{2}{|c|}{ westerly } \\
\hline
\end{tabular}

$\# \mathrm{~W}$ within $200 \mathrm{~km}$ from the west coast

$\# \mathrm{E}$ at least $200 \mathrm{~km}$ from the west coast

where the opposite is true, as along the coast of Oregon. The effect of reversals of the mean meridional wind appears to be relatively small. For instance, the ATR is $3 \mathrm{~K}$ less in Calcutta (with southerly winds in July and northerlies in
January) than in Hong Kong, which is at the same latitude of $22^{\circ} \mathrm{N}$ and similarly located north of an ocean, but without the seasonal reversal of the meridional component of the wind.

The prevailing winds in the central plains of the United States are westerly in winter and southerly is summer (Fig. 8). So the fetch is less in summer, when warm, moist air flows from the Gulf of Mexico under the influence of the Bermuda high. This is consistent with the gradient of July-average dewpoints, the dewpoint declines northwestwards from the Atlantic and Gulf coasts (Robinson, 1998, p. 1543). Wintertime dewpoint values are highest in the northwest and decrease eastward to the Great Plains, as Pacific storms progressing inland gradually lose their water vapor. The effect of this change in prevailing wind direction on the ATR appears small. The reason is that southerly winds advect very little heat in summer, because the Great Plains are about isothermal with the Gulf of Mexico.

In summary, the impact of the mean meridional wind component, and its seasonal variation, can be ignored for simplicity in estimating the ATR.

\subsection{Variation of annual range inland}

The variation of ATR across Eurasia at $50^{\circ} \mathrm{N}$ is shown in Fig. 9. Observed ATR values have been adjusted to a common latitude (Section 2.2), though the adjustment is small since all stations used in Fig. 9 lie between $48.2-51.1^{\circ} \mathrm{N}$. The transect is uniquely long, does not traverse any

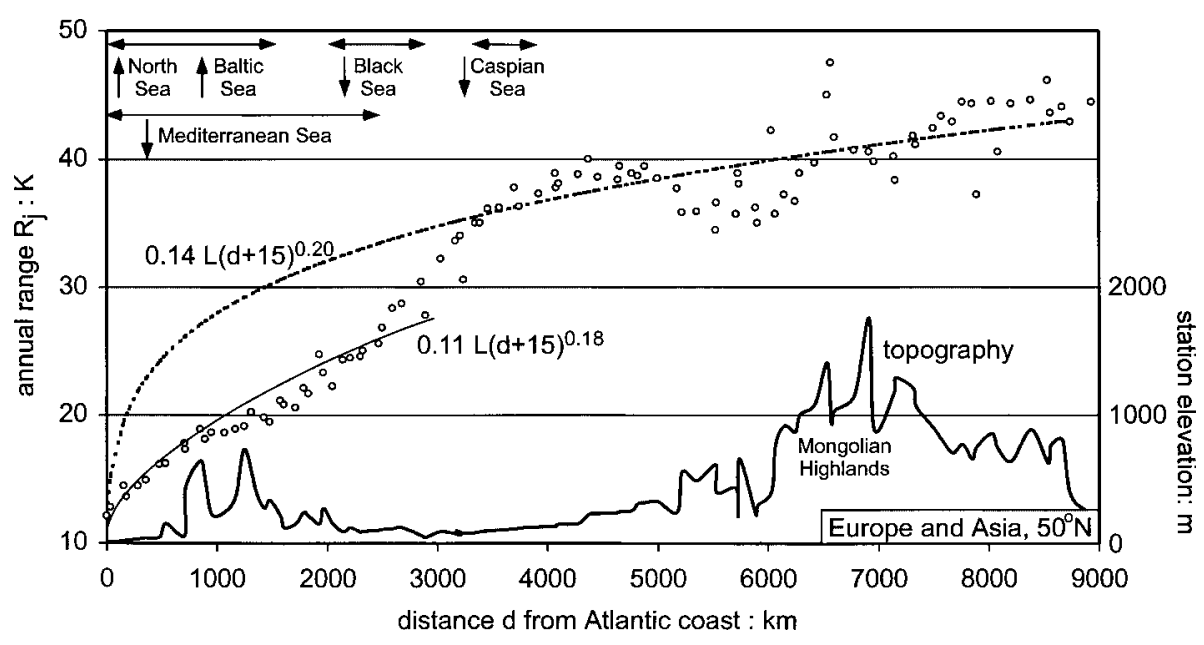

Fig. 9. The east-west variation of the apparent ATR $\mathrm{R}_{\mathrm{j}}$ across Eurasia at $50^{\circ} \mathrm{N}$, starting at the west coast of France. The horizontal arrows indicate the locations of adjacent seas to the north (upward arrow) or to the south (downward arrow). The 'topography' curve shows the station elevations 


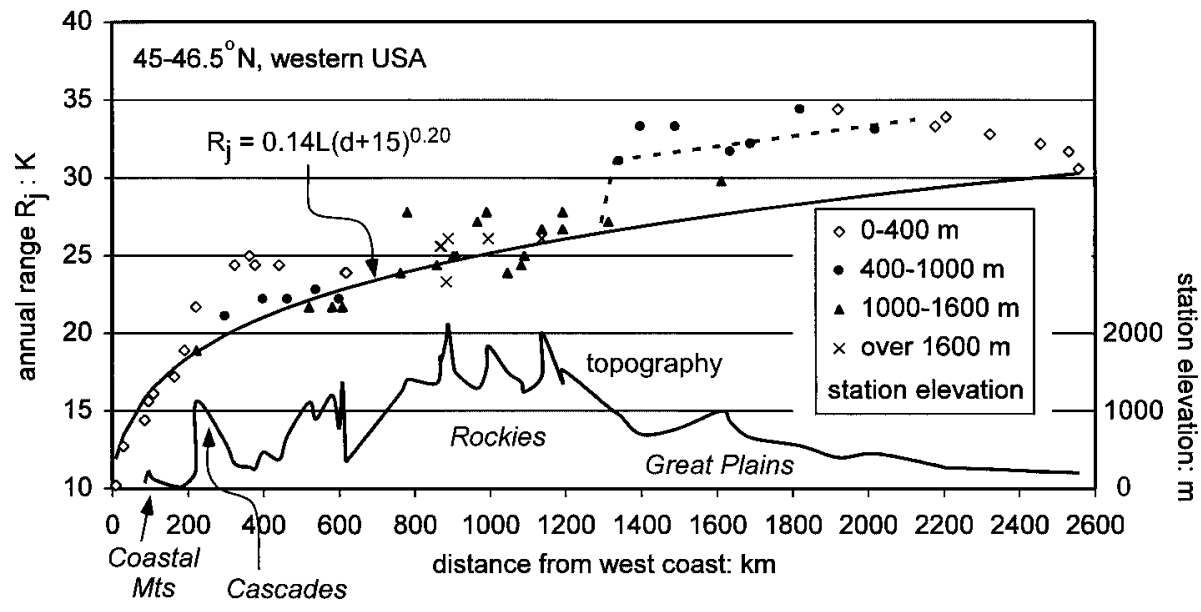

Fig. 10. Observed variation of ATR $R_{j}$ with distance from the west coast of the USA for stations at latitudes between $45-46.5^{\circ} \mathrm{N}$. The solid line corresponds to Eq. (3a), and the dashed line adds $3 \mathrm{~K}$ to the solid line in the Great Plains major mountain ranges, and is parallel to the prevailing westerly surface wind, so it demonstrates how fetch affects annual range in a particularly simple case.

Linacre (1969, p. 11) and Linacre (1992, p. 77) proposed that the ATR is proportional to the inland distance $\mathrm{d}(\mathrm{km})$ to the power ' $\mathrm{n}$ ', where $\mathrm{n}$ has a value between $0.15-0.44$, a typical value being 0.25. The Eurasian transect (Fig. 9) implies a power value of 0.18 until the Ukrainian plains, and 0.20 further inland. The illustrated curves are represented by the following equations for the apparent ATR, $\mathrm{R}_{\mathrm{je}}(\mathrm{K})$ :

$\mathrm{R}_{\mathrm{je}}=0.14 \mathrm{~L}(\mathrm{~d}+15)^{0.20} \mathrm{~K}$ for $\mathrm{d}>3000 \mathrm{~km}$

$\mathrm{R}_{\mathrm{je}}=0.11 \mathrm{~L}(\mathrm{~d}+15)^{0.18} \mathrm{~K}$ for $\mathrm{d}<3000 \mathrm{~km}$

where $\mathrm{L}$ is the absolute value of the latitude (degrees) and $\mathrm{d}$ the zonal distance inland $(\mathrm{km})$. The slope constant (0.14) in Eq. (3a) was chosen to minimise the bias in Fig. 9 and other transects, while Eq. (3b) results from a regression of the data shown in Fig. $9(\mathrm{~d}<3000 \mathrm{~km})$. The slope is less in Europe (Eq. 3b) than in Asia (Eq. 3a) because of the proximity to various inland seas to the north and south (listed in Fig. 9), which all contribute to moderate the ATR in Europe, as discussed below.

The number 15 in Eqs. (3) is necessary to allow for a non-zero ATR at the coast $(\mathrm{d}=0)$. The apparent ATR at coastal stations with prevailing onshore winds is about $9 \mathrm{~K}$ between $0-60^{\circ}$ latitude (Fig. 5) and Eq. $3 \mathrm{~b}$ shows that this implies a distance inland of roughly $15 \mathrm{~km}$ (i.e. $\left.[9 /(30 * 0.11)]^{1 / 0.18}\right)$, i.e. the ATR increases as though it starts from zero at a point $15 \mathrm{~km}$ off the upwind shore.

Equation (3) indicates that ATR estimation is not sensitive to errors in the inland distance: the relative error in ATR is only one fifth of the relative error in distance. This confirms that it is reasonable to reckon the fetch as effectively the zonal distance to the upwind shore, as a surrogate of the actual path.

Equation (3a) is shown to be a good approximation in a transect from the Pacific coast at about $46^{\circ} \mathrm{N}$ in North America (Fig. 10). A jump of about $3 \mathrm{~K}$ is highlighted by a dashed line at $1300 \mathrm{~km}$. This abrupt increase corresponds to eastern edge of the Rockies, and is explained as follows. The Great Plains east of the Rockies are frequented in winter by shallow cold currents, trapped in their southward progression by the Rockies. The ATR gradually declines to the value of Eq. (3a) further east, on account of warm-air intrusions arising over the Gulf of Mexico and the Gulf Stream, and possibly the moderating influence of the Great Lakes. Figure 10 and other transects suggest that Eq. (3a) is a suitable approximation for the inland variation of ATR in the northern hemisphere except Europe.

Two transects at $26^{\circ} \mathrm{S}$ and $32^{\circ} \mathrm{S}$ (Fig. 11) also show a peak ATR in the lee of a mountain range, the Andes. Note that the distance inland $d$ in Eq. (3) is calculated from the west coast on the west side of the Andes. East of the Andes it is calculated from the east coast at $26^{\circ} \mathrm{S}$, and from both east and west coasts at $32^{\circ} \mathrm{S}$ (Section 3.2), according to the prevailing winds (Table 1). Equation (3a) most appropriate on the west coast 


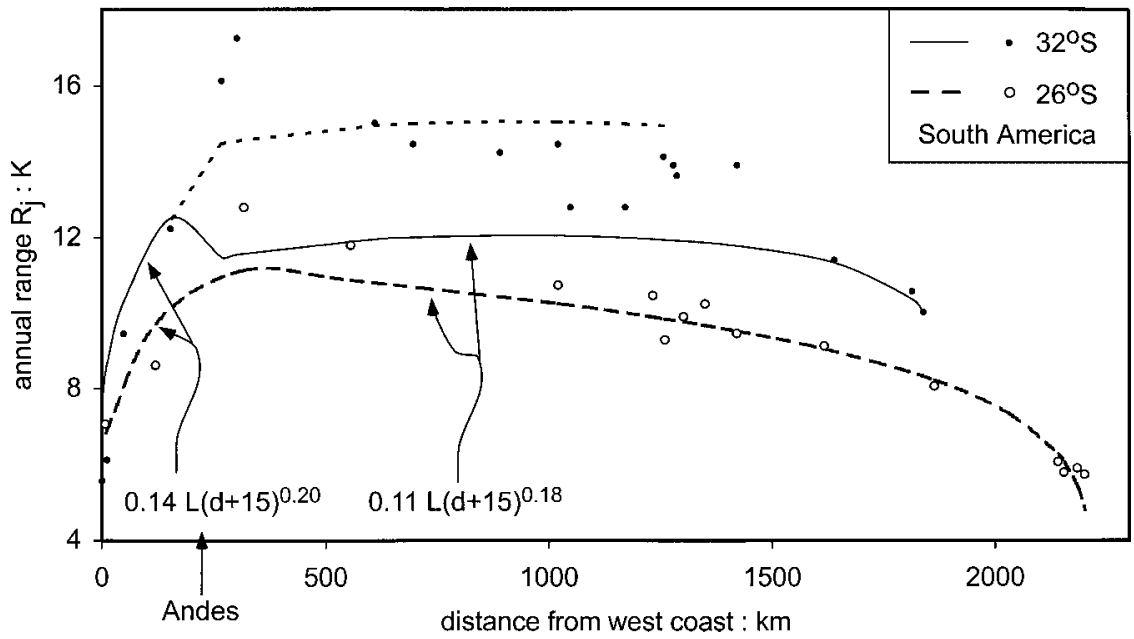

Fig. 11. As Fig. 10, but for South America at $26^{\circ} \mathrm{S}$ and $32^{\circ} \mathrm{S}$. The lines correspond to Eq. (3b), except within $200 \mathrm{~km}$ from the west coast, where Eq. (3a) is used. The short-dashed line adds $3 \mathrm{~K}$ to the solid line in the lee of the Andes at $32^{\circ} \mathrm{S}$ of South America, yet Eq. (3b) provides the best fit in South America east of the Andes, and across other southern continents (not shown). As in North America, the ATR is underestimated by about $3 \mathrm{~K}$ in the lee of the Andes at $32^{\circ} \mathrm{S}$.

The influence of topography on ATR will be discussed further in Section 4.

\subsection{Proximity to an ocean to the south or north}

The ATR at a place in the vicinity of an east-west oriented coastline is less than expected from the latitude and the distance to the zonally-upwind coast. For instance, the ATR at New Orleans $\left(30^{\circ} \mathrm{N}\right)$ is $3 \mathrm{~K}$ less than at Austin Texas, which is at the same latitude but closer to the upwind coast, i.e. the Pacific (Table 1). The influence of an ocean to the south or north decreases inland: the ATR increases at a rate of $1.1 \mathrm{~K} /{ }^{\circ}$ between New Orleans and St Louis to the north, more than twice the average rate over land (Section 2.2). The influence of a meridional ocean is most close to the coast. At low latitudes, and very close to the coast, this is due to sea breezes, which reduce the summer daytime maxima, and also the ATR. But the influence extends further inland than the typical sea breeze penetration depth, especially at higher latitudes. That is because of transient meridional winds, even where a westerly wind prevails. For instance, the passage of a frontal system implies a transition from poleward to equatorward winds. The cumulative effect of these transient winds appears significant in a belt $400-800 \mathrm{~km}$ wide from the coast to the south or north. Three transects in North America (Fig. 12)

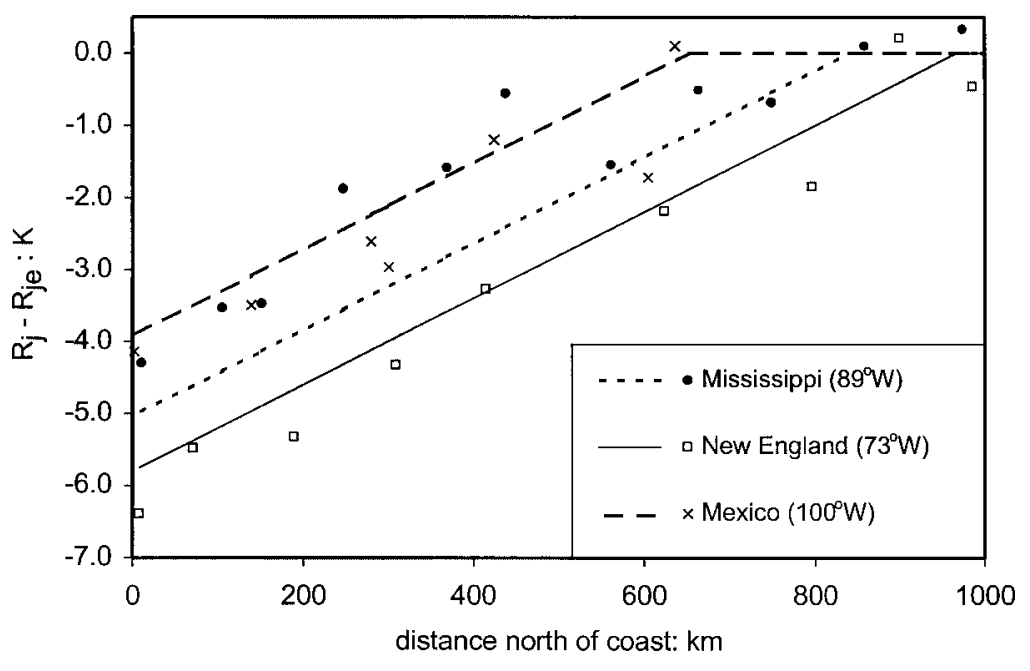

Fig. 12. Difference between observed ATR $R_{j}$ and estimated ATR $\mathrm{R}_{\mathrm{je}}$, according to Eq. (3a), as a function of distance from the coast to the south, for three meridional transects in North America 
suggest that in this belt the ATR is reduced by a factor $M$ (i.e. the meridional ocean factor),

$$
\begin{aligned}
\mathrm{M}= & 0.6-0.08 \mathrm{~L}-0.006(500-\delta \mathrm{y}) \mathrm{K} \\
& \text { and } \quad \mathrm{M} \leq 0
\end{aligned}
$$

where $\delta \mathrm{y}$ is the meridional distance from the coast $(\mathrm{km})$ and $\mathrm{L}$ the latitude $\left({ }^{\circ}\right)$. For instance, Halifax (Canada) at $44.5^{\circ} \mathrm{N}$ is $10 \mathrm{~km}$ north of the Atlantic, so the factor $\mathrm{M}$ is $-6 \mathrm{~K}$. Places where $\mathrm{M}$ has to be taken into account include the Gulf and East Coasts of North America, east of $95^{\circ} \mathrm{W}$, Central America $\left(85-103^{\circ} \mathrm{W}\right)$, and the south coast of West Africa, in a belt whose width $\delta y$ is determined by the requirement that $\mathrm{M}$ is negative. There are other north and south coasts, in Brazil, Australia and East Asia. Transects of the type shown in Fig. 12 indicate that no correction appears necessary in these regions. The factor $\mathrm{M}$ is halved if the zonal wind shifts seasonally (Section 3.2) and there is a long fetch over land in only one of the seasons.

\subsection{Effect of inland seas}

In LG02 it was shown that inland seas have no significant effect on the annual-mean temperature. The same is not true for the ATR (Fig. 3). The relatively low ATR in Eastern Europe (Fig. 9) is attributed to inland seas to the north and south, in particular the Mediterranean Sea. Therefore we examine the ATR at places along the Mediterranean coast of Africa (Fig. 13). The prevailing wind is westerly here, at least in winter (Table 1), so the distance is calculated from the west. There is a rapid ATR increase from $6 \mathrm{~K}$ at Tangier to $13-14 \mathrm{~K}$ at places about $400 \mathrm{~km}$ further east. This may be due to a topographic barrier (Section 4), i.e. the high terrain in southern Spain and northern Morocco, interrupted only by the Strait of Gibraltar. The 'latitudeadjusted' ATR in Western Europe starts at about the same value $(6 \mathrm{~K})$ as at $36^{\circ} \mathrm{N}$, but it increases more steadily inland, and it exceeds the ATR at the North African coast beyond $1200 \mathrm{~km}$ inland (Fig. 13). The ATR around the eastern Mediterranean Sea is quite uniform around $14 \mathrm{~K}$.

In short, the absence of an increase in ATR beyond $500 \mathrm{~km}$ along the African coast is attributed to the Mediterranean Sea. Therefore we will assume that the ATR for places within the coastal fringe of the Mediterranean is limited to that corresponding to $500 \mathrm{~km}$ from the Atlantic Ocean. The coastal fringe is about $75 \mathrm{~km}$ wide (LG02), in any direction.

Smaller seas and even lakes too may have an effect on the ATR (Fig. 3). For instance, the ATR in Milwaukee, on the upwind (western) side of Lake Michigan, is $2.7 \mathrm{~K}$ larger than at Muskegon $130 \mathrm{~km}$ downwind on the eastern shore. The ATR at Grand Rapids, just $60 \mathrm{~km}$ further in the interior of Michigan, is $1.8 \mathrm{~K}$ larger than at Muskegon, so the mitigating effect of a lake on the downwind ATR appears to be only local. The magnitude of this effect depends on the typical fetch over water and the lake's depth, which affects the ATR of the surface water.

In view of the evidence above, the influence of lakes and inland seas (other than the Mediterranean Sea) will be ignored in estimating the ATR.

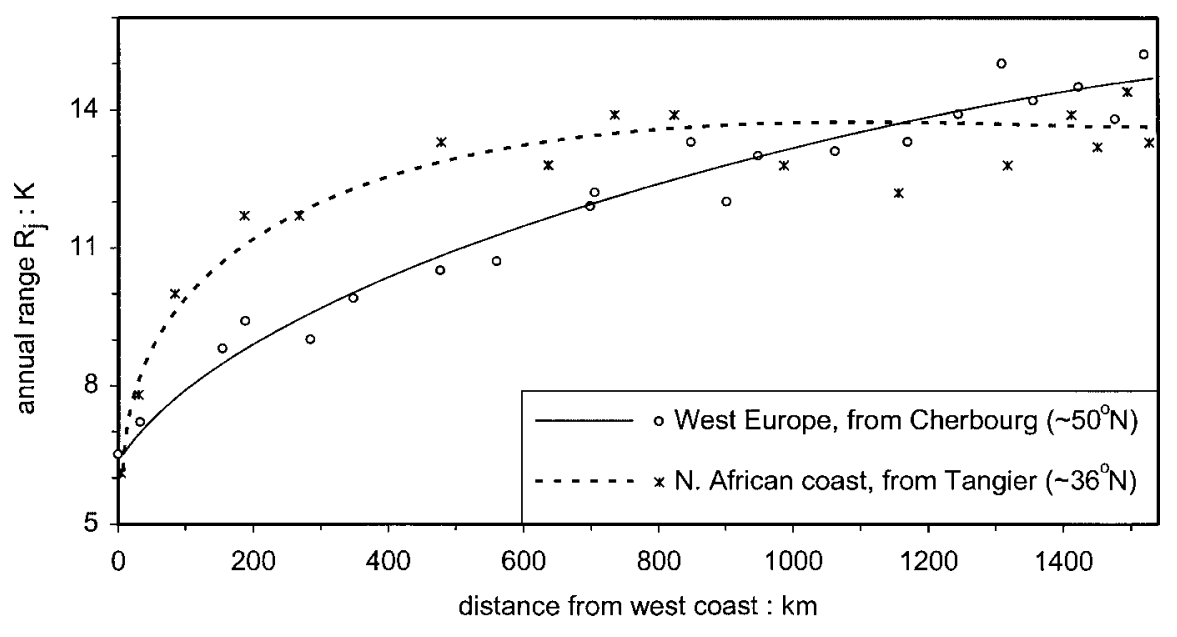

Fig. 13. The east-west variation of ATR $R_{j}$ along the North African coast, starting at Tangier on the Atlantic side of the Strait of Gibraltar. The range in Western Europe, 'corrected' to the latitude of $36^{\circ} \mathrm{N}$, has been added for comparison. The dashed line is a subjective best-fit line, and the solid line corresponds to Eq. (3b) 


\section{Effect of topography on the annual range}

\subsection{Elevation}

Elevation itself might directly affect the ATR, through reduced absorption of outgoing longwave radiation by a rarified atmosphere and more exposure to upper level winds. The difference between the lapse rate of January mean temperatures and that in July in the eastern Himalayas (Fig. 14) implies an ATR decrease with elevation of $1.1 \mathrm{~K} / \mathrm{km}$. A single side of the Tibetan Plateau was chosen to minimise the effect of various distances inland on ATR. Also, the mountain-barrier effect (Section 4.3) is insignificant in this case, because the prevailing wind direction is variable (Fig. 8).

The following four findings, selected for regions where the effects of distance inland and mountain barriers should be small, confirm this small decrease of ATR with elevation:

- data from places more than $300 \mathrm{~km}$ inland near $45^{\circ} \mathrm{N}$ in the western USA give a decrease of about $1.5 \mathrm{~K} / \mathrm{km}$;

- four places at about $45^{\circ} \mathrm{S}$ in New Zealand show $R_{j}$ values of $14.3 \mathrm{~K}$ at $218 \mathrm{~m}, 12.8 \mathrm{~K}$ at $356 \mathrm{~m}, 13.3 \mathrm{~K}$ at $800 \mathrm{~m}$ and $12.8 \mathrm{~K}$ at $1,830 \mathrm{~m}$ (L92, p. 76), i.e. a decrease of about $0.8 \mathrm{~K} / \mathrm{km}$;

- data from ten places in Switzerland (Section 4.2) suggest a decrease of $2.2 \mathrm{~K} / \mathrm{km}$.

- Hess (1968a) documents a decrease of $2.6 \mathrm{~K} / \mathrm{km}$ in the Eastern Alps and $1.7 \mathrm{~K} / \mathrm{km}$ in the Western Carpathians, using observations between $400-3050 \mathrm{~m}$ and between 230$2665 \mathrm{~m}$, respectively.

In short, the evidence indicates a typical ATR lapse rate with elevation at $1-2 \mathrm{~K} / \mathrm{km}$. The lapse rate may be proportional to latitude. Other factors than altitude clearly are at play, namely the distance inland, the barrier effect of mountains, and the shape of the local terrain, which controls the development of valley inversions in winter. This is illustrated in Fig. 15. At first glance the ATR appears independent of elevation, and it merely increases with latitude. The ATR at low-elevation stations around the Andes between $22-32^{\circ} \mathrm{S}$ has a large spread because the chosen stations lie both east and west of the Andes mountains. Marine airmasses on the west side of the Andes explain the small ATR there, but they do not cross the mountains. The ATR decreases with elevation at about $1.4 \mathrm{~K} / \mathrm{km}$ but only on the eastern side of the Andes between $22-32^{\circ} \mathrm{S}$.

Other topographic factors, discussed below, have a larger influence on ATR than elevation itself, in fact they may be responsible for the observed change of range with elevation. Therefore the elevation of a place will not be used in the quantitative estimation of its ATR based on geographical factors.

\subsection{Shape of the terrain}

The ATR tends to be greater in a valley than on an adjacent hilltop. The effect of complex terrain

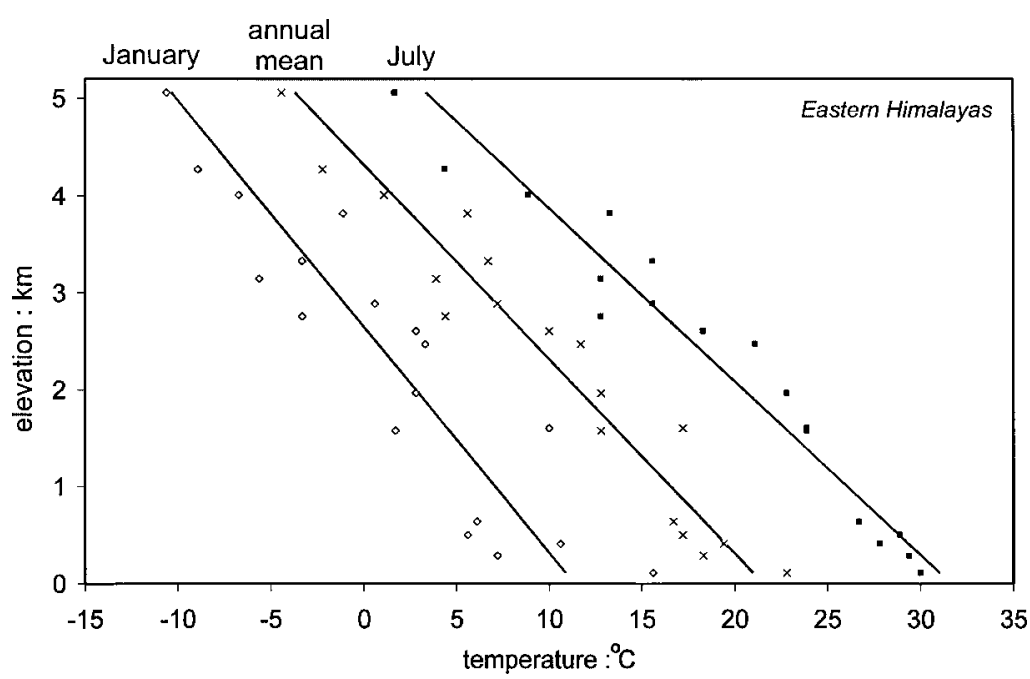

Fig. 14. Annual-mean temperatures and seasonal extremes at 18 places on the east side of the Himalayas/Tibetan Plateau, between $28-33^{\circ} \mathrm{N}, 93-104^{\circ} \mathrm{E}$ 


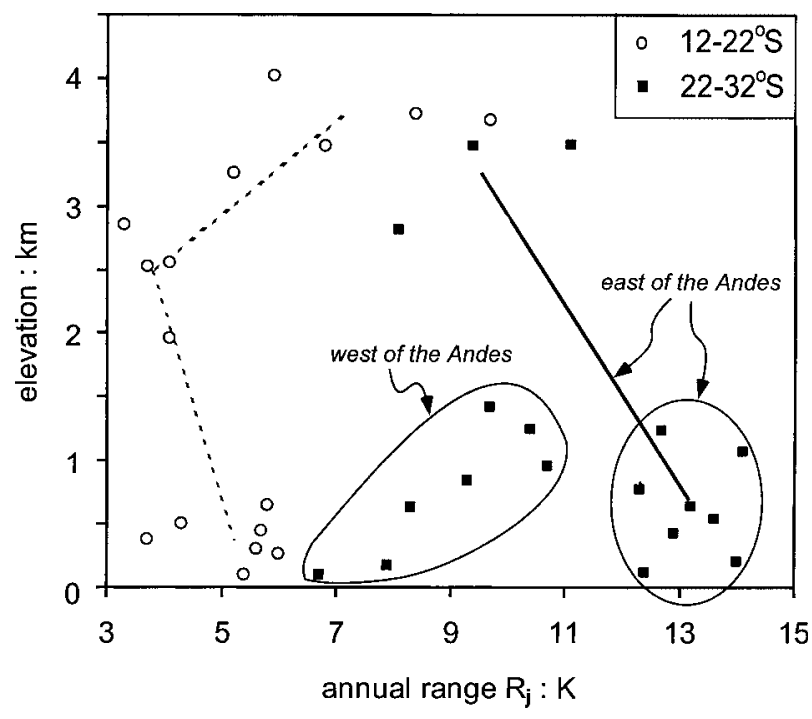

Fig. 15. Effect of elevation on the ATR $R_{j}$, at various altitudes around the Andes in South America

on ATR is apparent in Fig. 9: the station-tostation ATR difference is small in the first $5500 \mathrm{~km}$, which are flat, and greater around $6000<\mathrm{x}<8000 \mathrm{~km}$ over Mongolia's mountains. In Switzerland, the ATR in valleys is about $5 \mathrm{~K}$ larger than that on mountain tops at the same elevation (Fig. 16). Because the ATR in the free atmosphere aloft is not affected by terrain conditions below, this implies that the low-level static stability varies seasonally in mountainous regions. The lapse rate is close to dry-adiabatic in a deep boundary layer above a mountain valley in the summer, with only shallow, short-lived nocturnal inversions, but in winter cold air ponds in the valleys, causing deep inversions that may be strong enough to persist for many days, especially when a high-pressure region settles over the Alps. Deep inversions do not develop on mountains or hills, because cold air drains, and/or because of mixing by stronger winds. Several studies have documented lower minimum temperatures in valleys and lowlands, compared with that on hills and ridges, for instance in Germany (Geiger, 1965, p. 440), the Carpathian Mountains (Hess, 1968b, p. 63) and in northern Alaska (Zhang et al., 1996). The effect is more pronounced at higher latitudes, because of the larger amplitude of the annual cycle of radiative forcing, and in regions with weak winds.

The seasonal change in low-level stability is illustrated by means of station observations between 1951-1980 at 87 places in Wyoming, at elevations ranging from 1076 to $2888 \mathrm{~m}$ (Martner, 1986). The July mean lapse rate of daily maximum temperatures with station elevation is $5.6 \mathrm{~K} / \mathrm{km}$, while the January mean lapse rate of daily minima is only $1.3 \mathrm{~K} / \mathrm{km}$ for the same 87 stations. The correlation with elevation is strong in the former case (the correlation coefficient $\mathrm{r}=-0.82$ ), but weak in the latter $(\mathrm{r}=-0.14)$. That is because daily minima strongly depend on local terrain shape.

A topographic concavity factor has been contrived to quantify the effect of terrain shape on ATR. For a valley the concavity is defined as the average depth of the valley divided by the distance between the peaks or ridges on opposite sides. The concavity is zero for flat terrain. For a mountain location the concavity is negative (i.e. the terrain

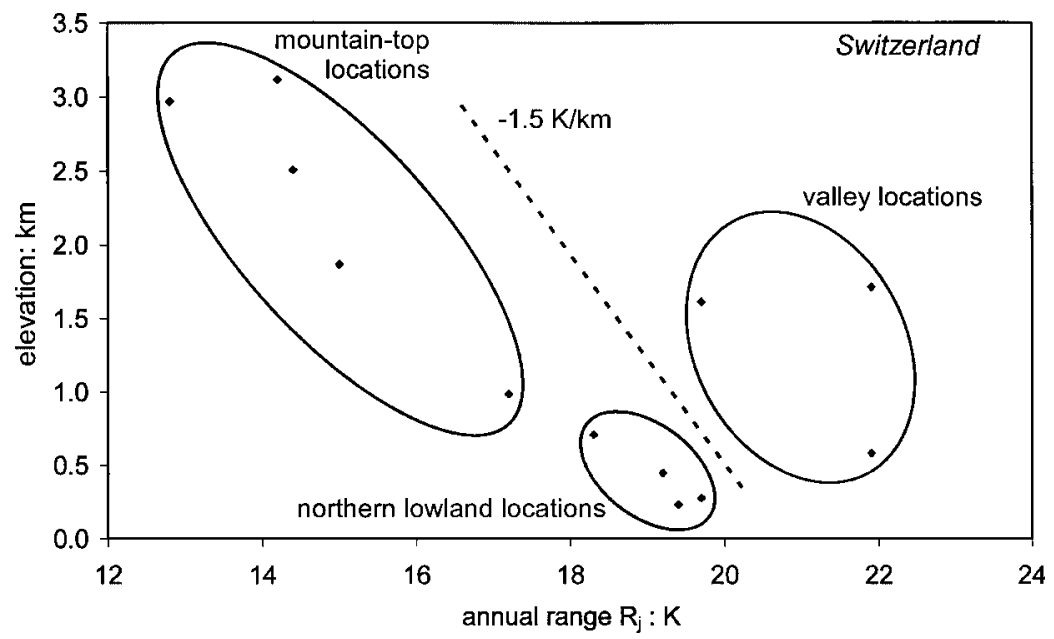

Fig. 16. Effect of elevation and terrain shape on the ATR $R_{j}$ in Switzerland. Linear regression gives a slope of $-2.2 \mathrm{~K} / \mathrm{km}$ for these 12 observations 


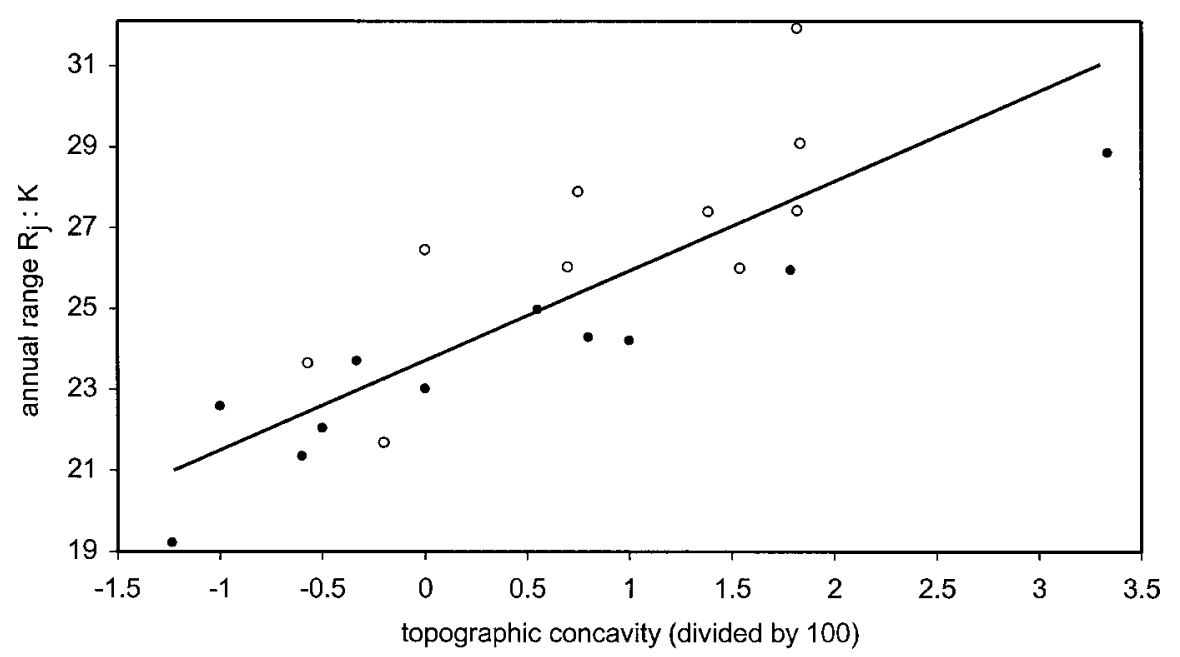

Fig. 17. The effect of the local topography on the ATR, for 21 ISMCS stations in Colorado and Wyoming, located between $37.5-44^{\circ} \mathrm{N}$ and $105-111^{\circ} \mathrm{W}$. The ATR is 'corrected' to a common latitude of $40^{\circ} \mathrm{N}$ assuming a range increase of $0.5 \mathrm{~K} /{ }^{\circ}$. The stations are at elevations ranging between $1429-3225 \mathrm{~m}$. The hollow circles refer to stations below $2100 \mathrm{~m}$, while the solid circles apply to stations above $2200 \mathrm{~m}$

is convex) and is the height of the mountain divided by its typical width. The derivation of a concavity factor from detailed topographic charts entails some inherent subjectivity. The scale of the relief that determines topographic concavity is the one that controls the thermally forced airflows. For instance, for a valley location, the main ridgeline above the valley should be used, rather than the distant mountain peaks.

Figure 17 shows that topographic concavity correlates well with ATR at 21 select stations in Colorado and Wyoming $(r=0.83)$. (The central Rocky Mountain region was chosen because of its variety of terrain, and its remoteness from an ocean.) Figure 17 confirms that higher-elevation places (shown as solid dots) tend to have a smaller ATR (Section 4.1). More significantly, places in terrain concavities generally experience a higher ATR than plain and ridge locations, no matter what their elevation above sea level is.

Landform clearly affects the ATR, at least at middle and high latitudes. It contributes to, or may be entirely responsible for, the observed decrease of ATR with elevation mentioned in Section 4.1: a linear regression of the 12 data points in Fig. 16 gives a lapse rate of $2.2 \mathrm{~K} / \mathrm{km}$, yet upon grouping stations according to local topography, this lapse rate can be seen to be smaller, about $1.5 \mathrm{~K} / \mathrm{km}$ (dashed line in Fig. 16). Places between $2-3 \mathrm{~km}$ in Fig. $15\left(12-22^{\circ} \mathrm{S}\right)$ are on the flanks of the Andes, while places above $3 \mathrm{~km}$ are on the Altiplano between the Cordilleras Occidental and Central, shielded from the oceans' influence. This may explain the slight increase of ATR with elevation above 2,500 $\mathrm{m}$ between $12-22^{\circ} \mathrm{S}$ (Fig. 15).

The shape of the terrain will not be included in the estimation of ATR, not because its effect is insignificant, but because topographic concavity is not a readily available geographic determinant, and because its effect probably varies with latitude and mean wind speed.

\subsection{Upwind topographic barriers}

The ATR increases inland more rapidly in North America (Fig. 10) than in Western Europe around the same latitude (Fig. 9), because the inland penetration of marine airmasses is blocked by high and continuous mountain ranges like the Cascade Mountains. These barriers allow the inland airmass to adjust to a radiative equilibrium over land, implying a large ATR. Therefore a place just inland of a coastal mountain range will have an ATR that, in the absence of mountains, would only be found much further inland. The strength of this 'barrier effect' can be measured in terms of the horizontal ATR gradient across a mountain ridge.

The Andes Mountains, for instance, act as an effective barrier, with a large east-to-west ATR 


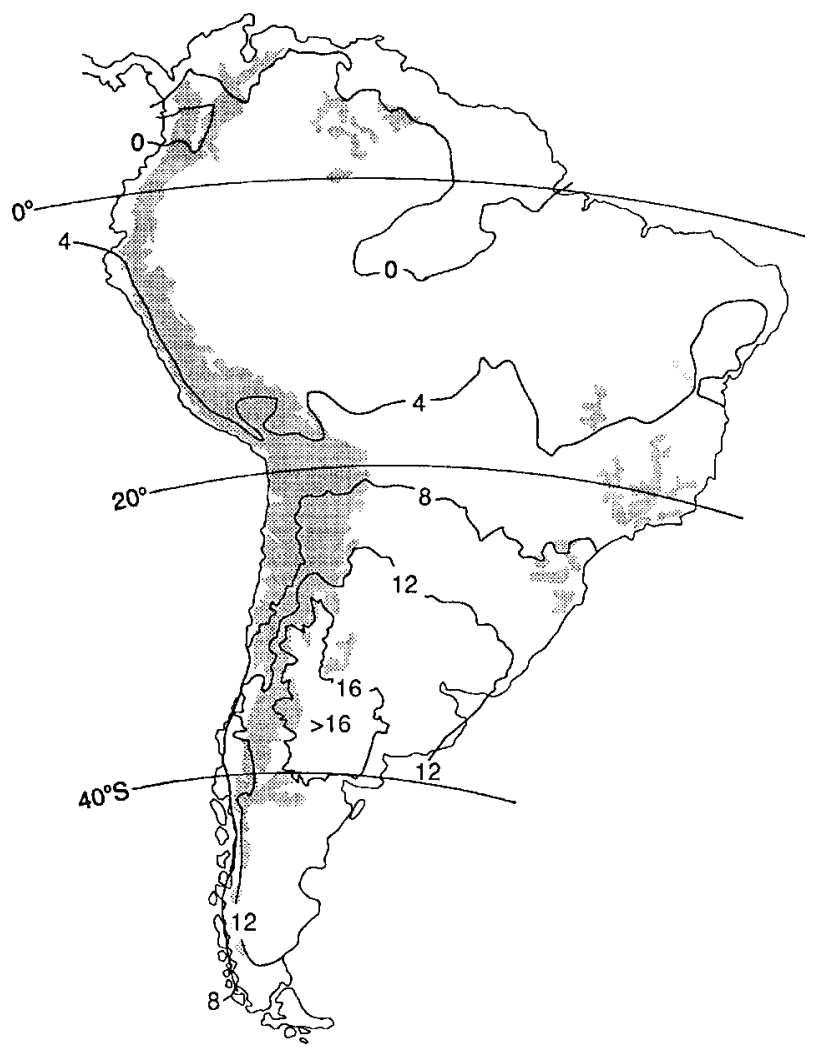

Fig. 18. The difference between January-mean and Julymean temperatures in South America (LG97, p. 63). The lines labeled zero separate places where January is hotter than July from those in the north, where the reverse is true. The shaded area shows mountains higher than 1,500 metres

difference at $22-32^{\circ} \mathrm{S}$ (Fig. 15) and especially around $30-40^{\circ} \mathrm{S}$ (Fig. 18). The Andes is high and continuous enough to separate airmasses, resulting in large gradients in temperature, humidity and wind direction. At low latitudes $\left(0-20^{\circ} \mathrm{S}\right)$, where easterlies prevail, the Andes confine humid equatorial air to the Amazon
Basin. Strong westerlies do cross the southern Andes $\left(30-50^{\circ} \mathrm{S}\right)$, which are lower, but the föhn effect dries out the transcending airmasses.

Two zonal transects across North America illustrate that mountain ranges coincide with sudden increases in ATR. The Cascades mainly act as a föhn barrier in winter and as an airmass separator in summer (Fig. 19). The coastal mountains at $50-100 \mathrm{~km}$ inland around $47^{\circ} \mathrm{N}$ have little effect, because they are low and contain large gaps. The much drier air on the downwind (eastern) side of the Cascades implies fewer clouds and therefore larger daily and also annual temperature ranges. Figure 20 demonstrates that the San Bernardino Mountains surrounding the Loss Angeles Basin effectively block the penetration of marine air eastward. Except during infrequent winter storm events, the marine air is capped by a subsidence inversion, and the ambient westerly winds are weaker than further north, therefore the mountains simply separate airmasses. The mean relative humidity drops dramatically over less than $200 \mathrm{~km}$, and the ATR increases from about $6 \mathrm{~K}$ near the coast to over $20 \mathrm{~K}$. The ATR hardly increases further inland (Fig. 20). Surface winds have mainly a westerly component in the transect of Fig. 20, but they are not persistent and southeasterly winds prevail in summer in the eastern half of the transect (Fig. 8). The latter advect moisture from the Gulf of Mexico, hence the mean relative humidity east of the Sangre de Christo Mountains is higher than that at intramountain places to the west, at the same altitude. As a result the ATR starts to decrease east of the continental divide near the Mogollon Plateau (Fig. 20).

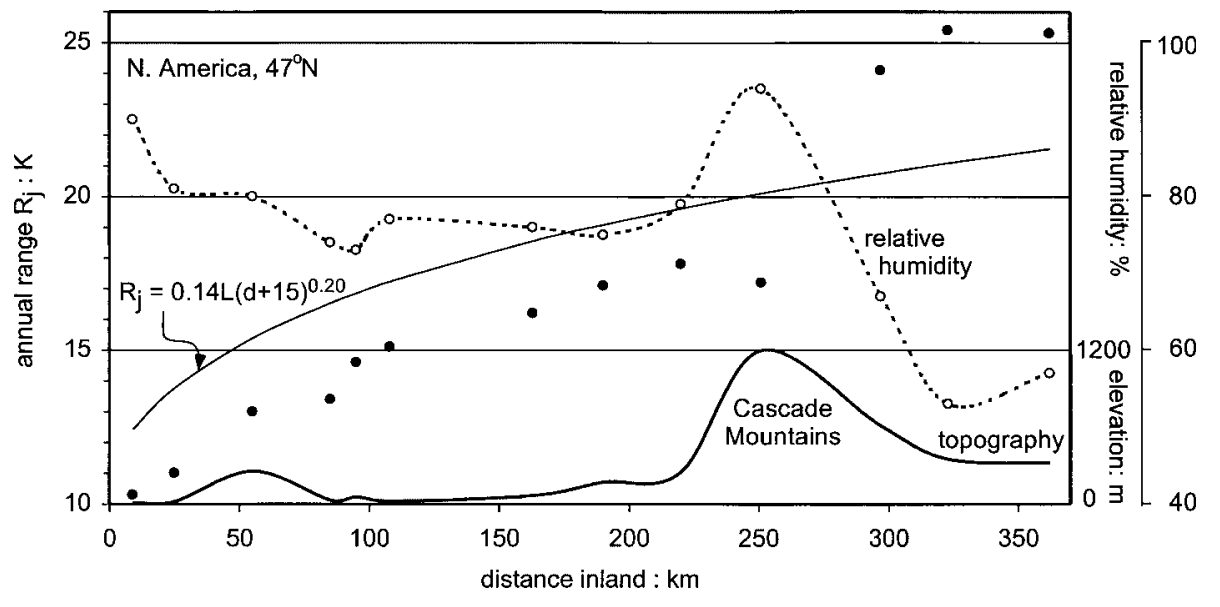

Fig. 19. The variation of ATR $\mathrm{R}_{\mathrm{j}}$ (solid circles) with distance from the west coast of the USA at $47^{\circ} \mathrm{N}$. The open circles and dashed line denote the corresponding annual-mean humidity. The thin line corresponds to Eq. (3a), and the bold line connects the station elevations 


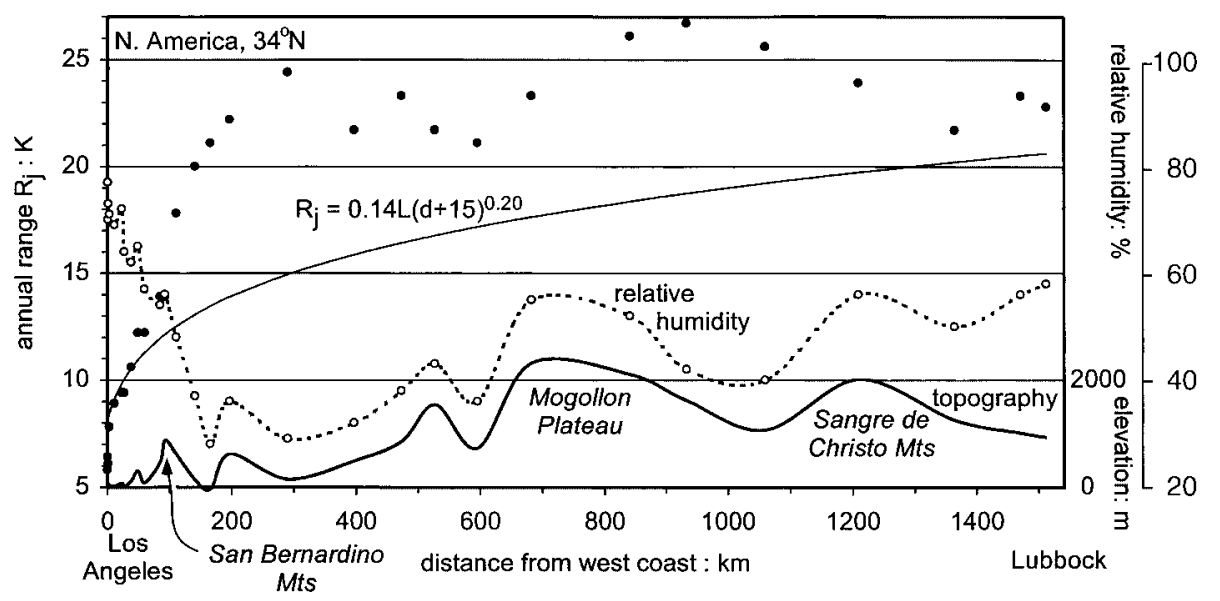

Fig. 20. As Fig. 19, but at $34^{\circ} \mathrm{N}$

It was shown in Section 3.3 that the mountain barrier effect enhanced the ATR by about $3 \mathrm{~K}$ above the value predicted by Eq. (3a), and that the effect did not extend far in the lee of the Rockies (Fig. 10) and the Andes (Fig. 11), in part because transient meridional winds reduce the ATR further to the east. The transect of Fig. 20 confirms the existence of an ATR barrier enhancement, $\mathrm{B}$, and its containment within about $1000 \mathrm{~km}$ downwind of the main mountain barrier.

The barrier enhancement is obvious also in the shorter transects from the coasts at Sydney and Los Angeles (Fig. 21). In both cases blocking terrain exists about $100 \mathrm{~km}$ inland. The Californian San Bernardino Mountains are higher than the Blue Mountains in Australia, but there are no stations on top of the former along the transect shown in Fig. 21. Equation 3 is a good approximation to the ATR across both coastal plains, and in both cases the best approximation includes a $3 \mathrm{~K}$ increment at the inland edge of the topographic barrier. Inland of Los Angeles a larger jump occurs, because of the greater height of the San Bernardino Mountains: this implies more effective blockage of marine airmasses, as demonstrated by the large humidity gradient across the mountains (Fig. 20). The ATR inland of Sydney decreases at a short distance west of the Blue Mountains, because of the influence of maritime airmasses frequenting this area from the (south)west, mainly in winter (Table 1).

In summary, mountain barriers enhance the ATR in two ways: they inhibit easy penetration of marine air inland, mainly at low latitudes (Fig. 20); and if the marine air does cross the barrier, which is more common at middle to high latitudes, it is drier on the lee-side, and drier, cloud-free air implies a larger ATR (Fig. 19). A

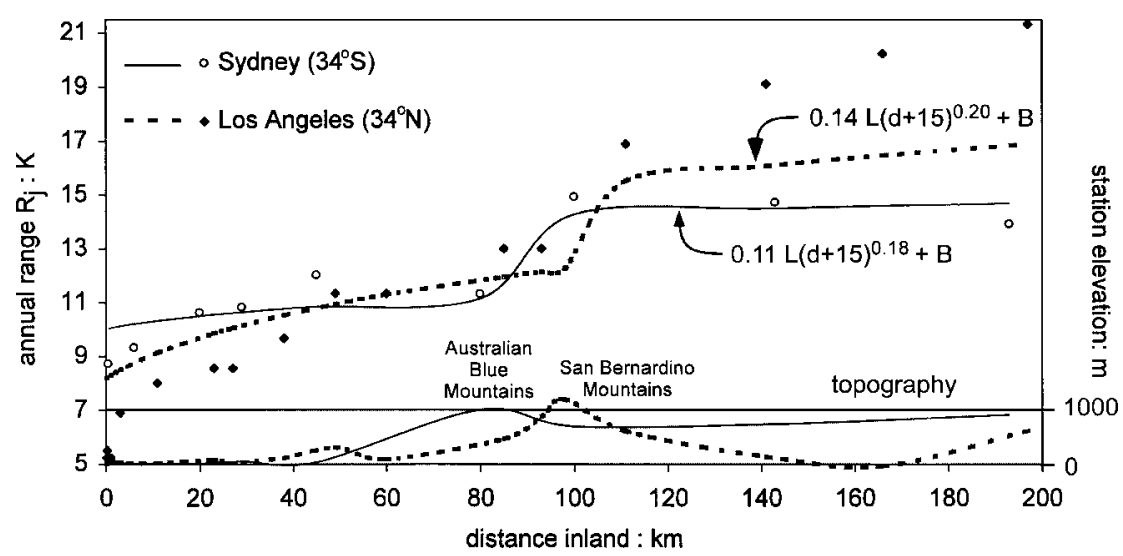

Fig. 21. The variation of the observed ATR $R_{j}$ with distance inland from Los Angeles (west coast) and Sydney (east coast), two places at the same latitude. The upper solid (dashed) line corresponds to Eq. (3b) for Sydney (Eq. 3a for Los Angeles), with the addition of $3 \mathrm{~K}$ inland of the mountain crest ("B"). The two lower lines show the respective profiles of station elevation 
Table 2. Regions in which the ATR is enhanced by the barrier effect $(\mathrm{B}=3 \mathrm{~K})$, as derived from Figs. 10, 11, 17, 19, and 20 and other transects. For instance, the barrier enhancement is applied in a $750 \mathrm{~km}$ wide belt east of the Andes between $30-40^{\circ} \mathrm{S}$

\begin{tabular}{llll}
\hline Continent & Latitude range & Relevant barrier & Width \\
\hline North America & $40-60^{\circ} \mathrm{N}$ & Rocky Mountains & $1000 \mathrm{~km}$ to the east \\
& $32-40^{\circ} \mathrm{N}$ & Sierra Nevada - San Bernardino & $1000 \mathrm{~km}$ to the east \\
South America & $30-40^{\circ} \mathrm{S}$ & Andes & $750 \mathrm{~km}$ to the east \\
Australia & $25-36^{\circ} \mathrm{S}$ & Dividing Range & $250 \mathrm{~km}$ to the west \\
\hline
\end{tabular}

Table 3. Estimation of true ATR $\mathrm{R}_{\mathrm{te}}$, in terms of the prevailing wind direction (westerly W or easterly E in winter/summer), the zonally-upwind distance from the sea $\mathrm{d}(\mathrm{km})$, and a correction either for the barrier enhancement $(\mathrm{B}=3 \mathrm{~K})$ or for the proximity to an ocean to the north or south $\mathrm{M}(\mathrm{K})$. The choice of the appropriate version of Eq. (5) is shown (a or b). The estimated value $\mathrm{R}_{\mathrm{te}}$ is compared to the observed range $\mathrm{R}_{\mathrm{t}}$. As in the Figures, southern latitudes are shown as negative, however $\mathrm{L}$ is positive in all equations

\begin{tabular}{|c|c|c|c|c|c|c|c|c|c|c|}
\hline $\begin{array}{l}\text { Location } \\
\text { (city, country) }\end{array}$ & $\begin{array}{l}\text { Latitude } \\
\text { L: }{ }^{\circ}\end{array}$ & $\begin{array}{l}\text { Wind } \\
\text { direction }\end{array}$ & $\begin{array}{l}\text { Winter } \\
\mathrm{d}: \mathrm{km}\end{array}$ & $\begin{array}{l}\text { Summer } \\
\mathrm{d}: \mathrm{km}\end{array}$ & $\begin{array}{l}\text { Correction } \\
\mathrm{B}+\mathrm{M}: \mathrm{K}\end{array}$ & Eq. & $\begin{array}{l}\text { Estimated } \\
\mathrm{R}_{\mathrm{te}}: \mathrm{K}\end{array}$ & $\begin{array}{l}\text { Observed } \\
\mathrm{R}_{\mathrm{t}}: \mathrm{K}\end{array}$ & $\begin{array}{l}\text { Error } \\
\mathrm{R}_{\mathrm{te}}-\mathrm{R}_{\mathrm{t}}: \mathrm{K}\end{array}$ & $\begin{array}{l}\text { Relative error } \\
\left(\mathrm{R}_{\mathrm{te}}-\mathrm{R}_{\mathrm{t}}\right) / \mathrm{R}_{\mathrm{t}}: \%\end{array}$ \\
\hline Bodo, Norway & 67.3 & $\mathrm{~W}$ & 1 & 1 & 0.0 & $\mathrm{~b}$ & 12.2 & 13.9 & -1.7 & -12 \\
\hline Trondheim, Norway & 63.5 & $\mathrm{~W}$ & 67 & 67 & 0.0 & $\mathrm{~b}$ & 15.5 & 16.1 & -0.6 & -4 \\
\hline Yellowknife, Canada & 62.5 & $\mathrm{~W}$ & 2460 & 2460 & 0.0 & $\mathrm{a}$ & 41.9 & 41.7 & 0.2 & 0 \\
\hline Churchill, Canada & 58.8 & $\mathrm{~W}$ & 2450 & 2450 & 0.0 & $\mathrm{a}$ & 39.5 & 37.2 & 2.2 & 6 \\
\hline Moscow, Russia & 56.0 & $\mathrm{~W}$ & 1800 & 1800 & 0.0 & $\mathrm{~b}$ & 24.1 & 26.1 & -2.0 & -8 \\
\hline Krakow, Poland & 50.0 & $\mathrm{~W}$ & 1300 & 1300 & 0.0 & $\mathrm{~b}$ & 20.5 & 19.4 & 1.0 & 5 \\
\hline Paris, France & 48.7 & $\mathrm{~W}$ & 280 & 280 & 0.0 & $\mathrm{~b}$ & 15.4 & 15.6 & -0.2 & -1 \\
\hline $\begin{array}{l}\text { Ulaan Baatar, } \\
\text { Mongolia }\end{array}$ & 48.0 & $\mathrm{~W}$ & 7950 & 7950 & 0.0 & $\mathrm{a}$ & 41.0 & 38.9 & 2.1 & 5 \\
\hline Halifax, Canada & 44.9 & $\mathrm{~W}$ & 4750 & 4750 & -5.9 & $\mathrm{a}$ & 28.9 & 27.8 & 1.1 & 4 \\
\hline Budapest, Hungary & 47.4 & $\mathrm{~W}$ & 1540 & 1540 & 0.0 & $\mathrm{~b}$ & 20.1 & 21.1 & -1.0 & -5 \\
\hline LaRochelle, France & 46.1 & $\mathrm{~W}$ & 7 & 7 & 0.0 & $\mathrm{~b}$ & 10.4 & 12.8 & -2.4 & -19 \\
\hline Madrid, Spain & 40.5 & $\mathrm{~W}$ & 430 & 430 & 0.0 & $\mathrm{~b}$ & 15.1 & 16.7 & -1.6 & -10 \\
\hline Portland OR, USA & 45.6 & $\mathrm{~W}$ & 105 & 105 & 0.0 & $\mathrm{a}$ & 17.2 & 16.1 & 1.1 & 7 \\
\hline Montreal, Canada & 45.3 & $\mathrm{~W}$ & 3900 & 3900 & -2.3 & $\mathrm{a}$ & 31.4 & 31.1 & 0.3 & 1 \\
\hline Chicago, USA & 42.0 & $\mathrm{~W}$ & 2970 & 2970 & 0.0 & $\mathrm{a}$ & 29.8 & 28.9 & 0.9 & 3 \\
\hline Laramie, USA & 41.3 & $\mathrm{~W}$ & 1540 & 1540 & 0.0 & $\mathrm{a}$ & 25.8 & 23.9 & 1.9 & 8 \\
\hline Lincoln NE, USA & 40.9 & $\mathrm{~W}$ & 2200 & 2200 & 3.0 & $\mathrm{a}$ & 30.4 & 31.1 & -0.7 & -2 \\
\hline Beijing, China & 40.0 & $\mathrm{~W} / \mathrm{E}$ & 10630 & 930 & 0.0 & $\mathrm{a}$ & 29.6 & 29.4 & 0.2 & 1 \\
\hline Lisbon, Portugal & 38.8 & $\mathrm{~W}$ & 15 & 15 & 0.0 & $\mathrm{a}$ & 11.5 & 12.2 & -0.7 & -6 \\
\hline Beirut, Lebanon & 33.8 & $\mathrm{~W}$ & 500 & 500 & 0.0 & $\mathrm{a}$ & 17.4 & 14.4 & 2.9 & 20 \\
\hline Casablanca, Morocco & 33.5 & $\mathrm{~W}$ & 10 & 10 & 0.0 & $\mathrm{a}$ & 9.8 & 10.0 & -0.2 & -2 \\
\hline Montgomery, USA & 32.3 & $\mathrm{~W}$ & 2812 & 2812 & -3.5 & $\mathrm{a}$ & 19.6 & 19.4 & 0.2 & 1 \\
\hline Jerusalem, Israel & 31.9 & $\mathrm{~W}$ & 500 & 500 & 0.0 & $\mathrm{a}$ & 16.5 & 15.6 & 1.0 & 6 \\
\hline New Orleans, USA & 30.0 & $\mathrm{~W}$ & 2210 & 2210 & -4.7 & $\mathrm{a}$ & 15.9 & 16.1 & -0.2 & -1 \\
\hline Miami, USA & 25.8 & $\mathrm{E}$ & 10 & 10 & 0.0 & $\mathrm{a}$ & 8.0 & 8.3 & -0.4 & -4 \\
\hline Hong Kong, China & 22.2 & $\mathrm{E} / \mathrm{W}$ & 4 & 13374 & 0.0 & $\mathrm{a}$ & 14.4 & 12.8 & 1.6 & 13 \\
\hline Mexico City, Mexico & 19.4 & $\mathrm{E}$ & 310 & 310 & -2.2 & $\mathrm{a}$ & 7.8 & 7.2 & 0.5 & 7 \\
\hline Bombay, India & 19.1 & $\mathrm{~W}$ & 3 & 3 & 0.0 & $\mathrm{a}$ & 6.1 & 6.1 & -0.1 & -1 \\
\hline Tomboctou, Mali & 16.8 & $\mathrm{E} / \mathrm{W}$ & 6150 & 1200 & 0.0 & $\mathrm{a}$ & 12.9 & 12.2 & 0.7 & 6 \\
\hline Dakar, Senegal & 14.7 & $\mathrm{E} / \mathrm{W}$ & 7190 & 2 & 0.0 & $\mathrm{a}$ & 9.3 & 7.2 & 2.1 & 29 \\
\hline $\begin{array}{l}\text { San Salvador, } \\
\text { El Salvador }\end{array}$ & 13.7 & $\mathrm{E} / \mathrm{W}$ & 600 & 60 & -3.1 & $\mathrm{a}$ & 4.0 & 2.8 & 1.3 & 45 \\
\hline Madras, India & 13.0 & $\mathrm{~W}$ & 580 & 580 & 0.0 & $\mathrm{a}$ & 8.0 & 8.3 & -0.4 & -4 \\
\hline Lagos, Nigeria & 6.6 & $\mathrm{E} / \mathrm{W}$ & 5010 & 1550 & -2.8 & $\mathrm{a}$ & 3.4 & 3.3 & 0.0 & 1 \\
\hline Belem, Brasil & -1.4 & $\mathrm{E}$ & 200 & 200 & 0.0 & $\mathrm{~b}$ & 2.0 & 1.1 & 0.9 & 82 \\
\hline Matadi, Congo & -5.8 & $\mathrm{E} / \mathrm{W}$ & 2940 & 140 & 0.0 & $\mathrm{~b}$ & 3.8 & 4.4 & -0.7 & -16 \\
\hline
\end{tabular}


Table 3 (continued)

\begin{tabular}{|c|c|c|c|c|c|c|c|c|c|c|}
\hline $\begin{array}{l}\text { Location } \\
\text { (city, country) }\end{array}$ & $\begin{array}{l}\text { Latitude } \\
\text { L: }{ }^{\circ}\end{array}$ & $\begin{array}{l}\text { Wind } \\
\text { direction }\end{array}$ & $\begin{array}{l}\text { Winter } \\
\mathrm{d}: \mathrm{km}\end{array}$ & $\begin{array}{l}\text { Summer } \\
\mathrm{d}: \mathrm{km}\end{array}$ & $\begin{array}{l}\text { Correction } \\
\mathrm{B}+\mathrm{M}: \mathrm{K}\end{array}$ & Eqn & $\begin{array}{l}\text { Estimated } \\
\mathrm{R}_{\mathrm{te}}: \mathrm{K}\end{array}$ & $\begin{array}{l}\text { Observed } \\
\mathrm{R}_{\mathrm{t}}: \mathrm{K}\end{array}$ & $\begin{array}{l}\text { Error } \\
\mathrm{R}_{\mathrm{te}}-\mathrm{R}_{\mathrm{t}}: \mathrm{K}\end{array}$ & $\begin{array}{l}\text { Relative error } \\
\left(\mathrm{R}_{\mathrm{te}}-\mathrm{R}_{\mathrm{t}}\right) / \mathrm{R}_{\mathrm{t}}: \%\end{array}$ \\
\hline Jakarta, Indonesia & -6.3 & $\mathrm{E} / \mathrm{W}$ & 20 & 110 & 0.0 & $\mathrm{~b}$ & 3.1 & 1.7 & 1.4 & 86 \\
\hline $\begin{array}{l}\text { Dar Es Salaam, } \\
\text { Tanzania }\end{array}$ & -6.9 & $\mathrm{E} / \mathrm{W}$ & 10 & 3050 & 0.0 & $\mathrm{~b}$ & 3.9 & 4.4 & -0.5 & -12 \\
\hline Lusaka, Zambia & -15.3 & $\mathrm{E}$ & 1300 & 1300 & 0.0 & $\mathrm{~b}$ & 7.5 & 8.3 & -0.8 & -10 \\
\hline Broome, Australia & -18.0 & $\mathrm{E}$ & 2530 & 2530 & 0.0 & $\mathrm{~b}$ & 9.4 & 9.2 & 0.3 & 3 \\
\hline $\begin{array}{l}\text { Pt. Hedland, } \\
\text { Australia }\end{array}$ & -20.3 & $\mathrm{E}$ & 3130 & 3130 & 0.0 & $\mathrm{~b}$ & 10.8 & 8.9 & 1.9 & 21 \\
\hline Antofagasta, Chile & -23.5 & $\mathrm{~W}$ & 7 & 7 & 0.0 & $\mathrm{a}$ & 7.3 & 6.1 & 1.2 & 19 \\
\hline $\begin{array}{l}\text { Alice Springs, } \\
\text { Australia }\end{array}$ & -23.8 & $\mathrm{E}$ & 1830 & 1830 & 0.0 & $\mathrm{~b}$ & 11.3 & 12.8 & -1.5 & -12 \\
\hline $\begin{array}{l}\text { Asunction, } \\
\text { Paraguay }\end{array}$ & -25.3 & $\mathrm{E}$ & 930 & 930 & 0.0 & $\mathrm{~b}$ & 10.7 & 9.4 & 1.2 & 13 \\
\hline $\begin{array}{l}\text { Geraldton, } \\
\text { Australia }\end{array}$ & -28.8 & $\mathrm{~W} / \mathrm{E}$ & 2 & 3700 & 0.0 & $\mathrm{~b}$ & 10.6 & 8.6 & 2.0 & 23 \\
\hline Durban, S. Africa & -30.0 & $\mathrm{~W} / \mathrm{E}$ & 1350 & 8 & 0.0 & $\mathrm{~b}$ & 9.9 & 8.3 & 1.6 & 19 \\
\hline Perth, Australia & -31.9 & $\mathrm{~W} / \mathrm{E}$ & 16 & 1220 & 0.0 & $\mathrm{~b}$ & 10.5 & 11.1 & -0.6 & -5 \\
\hline Santiago, Chile & -33.4 & $\mathrm{~W}$ & 82 & 82 & 0.0 & $\mathrm{a}$ & 12.6 & 12.8 & -0.2 & -2 \\
\hline Sydney, Australia & -33.8 & $\mathrm{~W} / \mathrm{E}$ & 1480 & 3 & 0.0 & $\mathrm{~b}$ & 10.9 & 10.6 & 0.4 & 4 \\
\hline $\begin{array}{l}\text { Cape Town, } \\
\text { S. Africa }\end{array}$ & -34.0 & $\mathrm{~W} / \mathrm{E}$ & 6 & 780 & 0.0 & $\mathrm{~b}$ & 10.3 & 8.3 & 2.0 & 24 \\
\hline Mildura, Australia & -34.2 & $\mathrm{~W} / \mathrm{E}$ & 430 & 810 & 0.0 & $\mathrm{~b}$ & 12.8 & 14.4 & -1.6 & -11 \\
\hline $\begin{array}{l}\text { San Rafael, } \\
\text { Argentina }\end{array}$ & -34.6 & $\mathrm{~W} / \mathrm{E}$ & 490 & 840 & 3.0 & $\mathrm{~b}$ & 16.1 & 15.6 & 0.6 & 4 \\
\hline $\begin{array}{l}\text { Buenos Aires, } \\
\text { Argentina }\end{array}$ & -34.8 & $\mathrm{~W} / \mathrm{E}$ & 1270 & 50 & 0.0 & $\mathrm{~b}$ & 11.9 & 13.9 & -2.0 & -15 \\
\hline $\begin{array}{l}\text { Wagga Wagga, } \\
\text { Australia }\end{array}$ & -35.2 & $\mathrm{~W} / \mathrm{E}$ & 1130 & 85 & 3.0 & $\mathrm{~b}$ & 15.2 & 15.6 & -0.4 & -3 \\
\hline $\begin{array}{l}\text { Mt Gambier, } \\
\text { Australia }\end{array}$ & -37.8 & $\mathrm{~W}$ & 35 & 35 & 0.0 & $\mathrm{~b}$ & 9.2 & 9.2 & 0.0 & 0 \\
\hline
\end{tabular}

representative value for the mountain barrier enhancement $\mathrm{B}$ is $3 \mathrm{~K}$. The regions where this effect is significant are summarised in Table 2.

\section{Estimating the annual range}

Corrections for elevation (Section 4.1), for the shape of the local terrain (Section 4.2), and for inland seas except the Mediterranean Sea (Section 3.5), are small or uncertain compared with the influences of latitude and fetch. The following first-order estimate $R_{\text {te }}$ for the true ATR is proposed:

$$
\begin{aligned}
& \mathrm{R}_{\mathrm{te}}=0.14 \mathrm{~L}(\mathrm{~d}+15)^{0.2}+\mathrm{A}+\mathrm{B}+\mathrm{MK} \\
& \mathrm{R}_{\mathrm{te}}=0.11 \mathrm{~L}(\mathrm{~d}+15)^{0.18}+\mathrm{A}+\mathrm{B}+\mathrm{MK}
\end{aligned}
$$

Equation (5) is identical to Eq. (3), with adjustments for (a) apparent ATR deficit (A, see Fig. 2) as estimated by Eq. (1b) the mountain barrier enhancement B (Table 2), and (c) the presence of an ocean to the south or north (M, given by Eq. 4). Equation (5b) applies in Europe $\left(40-70^{\circ} \mathrm{N}\right.$, $\mathrm{d}<3000 \mathrm{~km}$ ) and for all southern-hemisphere locations, except in South America west of the Andes $(\mathrm{d}<200 \mathrm{~km})$. Equation (5a) applies elsewhere. For places within the 'fringe' of the Mediterranean Sea (i.e. within $75 \mathrm{~km}$ ), the distance inland $\mathrm{d}$ is the lesser of the actual distance from the Atlantic Ocean, and $500 \mathrm{~km}$. Table 1 is needed to determine the zonal wind direction. If according to Table 1 the wind directions change seasonally, then one adopts the procedure outlined in Section 3.2: at Shanghai for instance one calculates the ATR as the average of $R_{t e}$ for a station $10,000 \mathrm{~km}$ inland from the Atlantic, and $\mathrm{R}_{\mathrm{te}}$ for an east coast site at that latitude.

The estimation of true ATR (Eq. 5) has been tested for a selection of 54 places (Table 3). Their locations differed widely as regards distance 
from the sea (between 1 and $8000 \mathrm{~km}$ ) and latitude (between $38^{\circ} \mathrm{S}$ and $67^{\circ} \mathrm{N}$ ). The mean bias for the 54 examples in Table 3 is $+0.3 \mathrm{~K}$, with an mean absolute error of $1.0 \mathrm{~K}$. The relative error averages at $6 \%$ but is typically much larger at places with a small ATR. Therefore it tends to decrease with latitude, however poleward of $15-20^{\circ}$ it is rather independent of latitude.

The mean absolute error is of the same order of magnitude as that of the various effects ignored in the estimation procedure. Some large errors in Table 3 can be interpreted in the context of these effects. For instance, an enhanced exposure to marine influence would explain ATR overestimates at Halifax (on a peninsula jutting out into the Atlantic Ocean), Beirut (with a long fetch over the Mediterranean, and a mountain barrier to the east), and Capetown or Dakar (both on a cape surrounded by ocean). And the July temperature at Churchill is $3.6 \mathrm{~K}$ lower than at Brochet Man, located some $420 \mathrm{~km}$ west of Churchill. The latter is at the shore of the Hudson Bay. January temperatures at these two places are identical within $0.5 \mathrm{~K}$, because of the ice cover over the Hudson Bay. The result is that the Churchill ATR is overestimated by some $2 \mathrm{~K}$.

\section{January and July mean temperatures}

January and July mean temperatures can be estimated by combining the apparent ATR $\mathrm{R}_{\mathrm{je}}$ given in Eq. (5) (without the term A) with the annualmean temperature $T_{e}$, derived in a previous paper (LG02). For the latter, the 'look-up method' is used (LG02). Monthly-mean estimates are given by $\left[T_{e} \pm 1 / 2 R_{j e}\right]$. Table 4 shows a comparison of these estimates with observed values for the 54 places listed in Table 3.

The absolute errors span from 0.1 to $2.6 \mathrm{~K}$, and their average (for 54 stations and two months) is $1.0 \mathrm{~K}$. On average, the January (July) temperature estimates are $0.03 \mathrm{~K}(0.19 \mathrm{~K})$ too high. The absolute error of the July and January temperature estimates is independent of latitude and distance inland $(|\mathrm{r}|<0.20)$. Some errors can be attributed largely to the ATR estimation, e.g. the ATR is under-estimated for Perth and La Rochelle, while it is overestimated for Ulaan Baatar. In other cases the error in annual-mean temperature estimation dominates, e.g. $\mathrm{T}_{\mathrm{e}}$ values are too high for Moscow and Chicago, while they are too low in Yellowknife, Lisbon and Mildura. The mean absolute error for seasonal temperature estimates $(1.0 \mathrm{~K})$ combines the uncertainties of annual mean and range, therefore it is larger than the contributing errors alone, i.e. that of the annual-mean estimate (0.7 K, LG02), as well as half of the ATR error $(0.5 \mathrm{~K}$, Section 5$)$.

The estimates of annual mean temperature and its seasonal range can further be used to approximate the mean temperature for any month, at

Table 4. Validation of empirically estimated January and July mean temperatures, $\mathrm{T}_{\mathrm{e}, \mathrm{jan}}$ and $\mathrm{T}_{\mathrm{e}, \mathrm{jul}}$, for the locations listed in Table 3. The estimation uses the annual-mean temperature $T_{e}$ (based on the look-up method, LG02) and the ATR (Section 5). The error $\left(\Delta \mathrm{T}_{\mathrm{jan}}\right)$ is the difference between estimation $\left(\mathrm{T}_{\mathrm{e}, \mathrm{jan}}\right)$ and observation $\left(\mathrm{T}_{\mathrm{jan}}\right)$

\begin{tabular}{|c|c|c|c|c|c|c|c|c|c|}
\hline \multirow[t]{2}{*}{ Location (city, country) } & \multirow{2}{*}{$\begin{array}{l}\text { Annual } \\
\text { mean } \\
\mathrm{T}_{\mathrm{e}}:{ }^{\circ} \mathrm{C}\end{array}$} & \multicolumn{2}{|c|}{ Annual range } & \multicolumn{3}{|c|}{ January mean temperature } & \multicolumn{3}{|c|}{ July mean temperature } \\
\hline & & $\begin{array}{l}\text { True } \\
\mathrm{R}_{\mathrm{te}}: \mathrm{K}\end{array}$ & $\begin{array}{l}\text { Apparent } \\
\mathrm{R}_{\mathrm{je}}: \mathrm{K}\end{array}$ & $\begin{array}{l}\text { Estimated } \\
\mathrm{T}_{\mathrm{e}, \mathrm{jan}}:^{\circ} \mathrm{C}\end{array}$ & $\begin{array}{l}\text { Observed } \\
\mathrm{T}_{\mathrm{jan}} \cdot{ }^{\circ} \mathrm{C}\end{array}$ & $\begin{array}{l}\text { Error } \\
\Delta \mathrm{T}_{\mathrm{jan}}: \mathrm{K}\end{array}$ & $\begin{array}{l}\text { Estimated } \\
\mathrm{T}_{\mathrm{e}, \mathrm{jul}}:^{\circ} \mathrm{C}\end{array}$ & $\begin{array}{l}\text { Observed } \\
\mathrm{T}_{\text {jul }}{ }^{\circ} \mathrm{C}\end{array}$ & $\begin{array}{l}\text { Error } \\
\Delta \mathrm{T}_{\mathrm{jul}}: \mathrm{K}\end{array}$ \\
\hline Bodo, Norway & 4.3 & 12.2 & 12.2 & -1.8 & -1.7 & -0.1 & 10.4 & 12.8 & -2.4 \\
\hline Trondheim, Norway & 5.7 & 15.5 & 15.4 & -2.0 & -2.2 & 0.2 & 13.4 & 14.4 & -1.0 \\
\hline Yellowknife, Canada & -6.1 & 41.9 & 41.8 & -26.9 & -25.0 & -1.9 & 14.8 & 16.7 & -1.9 \\
\hline Churchill, Canada & -5.6 & 39.5 & 39.3 & -25.1 & -25.0 & -0.1 & 14.0 & 12.2 & 1.8 \\
\hline Moscow, Russia & 5.9 & 24.1 & 23.8 & -6.0 & -8.9 & 2.9 & 17.8 & 17.2 & 0.6 \\
\hline Krakow, Poland & 8.7 & 20.5 & 20.0 & -1.3 & -2.2 & 0.9 & 18.7 & 17.2 & 1.5 \\
\hline Paris, France & 11.2 & 15.4 & 14.9 & 3.7 & 3.9 & -0.1 & 18.7 & 19.4 & -0.8 \\
\hline Ulaan Baatar, Mongolia & -2.0 & 41.0 & 40.5 & -22.3 & -21.1 & -1.1 & 18.3 & 17.8 & 0.5 \\
\hline Halifax, Canada & 5.5 & 28.9 & 28.3 & -8.6 & -5.6 & -3.1 & 19.6 & 18.3 & 1.3 \\
\hline Budapest, Hungary & 10.3 & 20.1 & 19.6 & 0.5 & -0.6 & 1.1 & 20.1 & 20.6 & -0.5 \\
\hline
\end{tabular}


Table 4 (continued)

\begin{tabular}{|c|c|c|c|c|c|c|c|c|c|}
\hline \multirow[t]{2}{*}{ Location (city, country) } & \multirow{2}{*}{$\begin{array}{l}\text { Annual } \\
\text { mean } \\
\mathrm{T}_{\mathrm{e}}:{ }^{\circ} \mathrm{C}\end{array}$} & \multicolumn{2}{|c|}{ Annual range } & \multicolumn{3}{|c|}{ January mean temperature } & \multicolumn{3}{|c|}{ July mean temperature } \\
\hline & & $\begin{array}{l}\text { True } \\
\mathrm{R}_{\mathrm{te}}: \mathrm{K}\end{array}$ & $\begin{array}{l}\text { Apparent } \\
\mathrm{R}_{\mathrm{je}}: \mathrm{K}\end{array}$ & $\begin{array}{l}\text { Estimated } \\
\mathrm{T}_{\mathrm{e}, \mathrm{jan}}:{ }^{\circ} \mathrm{C}\end{array}$ & $\begin{array}{l}\text { Observed } \\
\mathrm{T}_{\mathrm{jan}}:{ }^{\circ} \mathrm{C}\end{array}$ & $\begin{array}{l}\text { Error } \\
\Delta \mathrm{T}_{\mathrm{jan}}: \mathrm{K}\end{array}$ & $\begin{array}{l}\text { Estimated } \\
\mathrm{T}_{\mathrm{e}, \mathrm{jul}}:{ }^{\circ} \mathrm{C}\end{array}$ & $\begin{array}{l}\text { Observed } \\
\mathrm{T}_{\text {jul }}:{ }^{\circ} \mathrm{C}\end{array}$ & $\begin{array}{l}\text { Error } \\
\Delta \mathrm{T}_{\mathrm{jul}}: \mathrm{K}\end{array}$ \\
\hline LaRochelle, France & 13.7 & 10.4 & 9.8 & 8.8 & 7.2 & 1.6 & 18.6 & 20.0 & -1.4 \\
\hline Madrid, Spain & 14.7 & 15.1 & 14.4 & 7.5 & 6.7 & 0.9 & 21.9 & 23.3 & -1.5 \\
\hline Portland OR, USA & 11.2 & 17.2 & 16.6 & 2.9 & 3.9 & -1.0 & 19.5 & 20.0 & -0.5 \\
\hline Montreal, Canada & 5.8 & 31.4 & 30.9 & -9.6 & -10.0 & 0.4 & 21.2 & 21.1 & 0.1 \\
\hline Chicago, USA & 10.5 & 29.8 & 29.1 & -4.1 & -6.1 & 2.0 & 25.1 & 22.8 & 2.3 \\
\hline Laramie, USA & 4.9 & 25.8 & 25.1 & -7.7 & -6.1 & -1.6 & 17.5 & 17.8 & -0.3 \\
\hline Lincoln NE, USA & 9.6 & 30.4 & 29.7 & -5.3 & -5.6 & 0.3 & 24.5 & 25.6 & -1.1 \\
\hline Beijing, China & 11.4 & 29.6 & 28.9 & -3.1 & -3.3 & 0.3 & 25.9 & 26.1 & -0.3 \\
\hline Lisbon, Portugal & 14.9 & 11.5 & 10.7 & 9.5 & 10.6 & -1.0 & 20.3 & 22.8 & -2.5 \\
\hline Beirut, Lebanon & 19.6 & 17.4 & 16.5 & 11.4 & 11.7 & -0.3 & 27.8 & 26.1 & 1.7 \\
\hline Casablanca, Morocco & 17.6 & 9.8 & 8.9 & 13.1 & 12.8 & 0.4 & 22.1 & 22.8 & -0.7 \\
\hline Montgomery, USA & 18.2 & 19.6 & 18.7 & 8.9 & 8.3 & 0.5 & 27.5 & 27.8 & -0.2 \\
\hline Jerusalem, Israel & 16.1 & 16.5 & 15.6 & 8.3 & 7.8 & 0.5 & 23.9 & 22.8 & 1.1 \\
\hline New Orleans, USA & 21.4 & 15.9 & 14.9 & 14.0 & 11.7 & 2.3 & 28.8 & 27.8 & 1.1 \\
\hline Miami, USA & 23.2 & 8.0 & 6.9 & 19.8 & 20.0 & -0.2 & 26.6 & 28.3 & -1.7 \\
\hline Hong Kong, China & 22.5 & 14.4 & 13.2 & 15.9 & 16.7 & -0.8 & 29.1 & 29.4 & -0.3 \\
\hline Mexico City, Mexico & 16.5 & 7.8 & 6.5 & 13.3 & 13.3 & -0.1 & 19.7 & 18.9 & 0.9 \\
\hline Bombay, India & 27.0 & 6.1 & 4.8 & 24.6 & 23.9 & 0.7 & 29.4 & 28.3 & 1.1 \\
\hline Tomboctou, Mali & 27.0 & 12.9 & 11.6 & 21.2 & 21.1 & 0.1 & 32.8 & 33.3 & -0.5 \\
\hline Dakar, Senegal & 25.1 & 9.3 & 7.9 & 21.2 & 21.1 & 0.0 & 29.0 & 27.2 & 1.8 \\
\hline $\begin{array}{l}\text { San Salvador, } \\
\text { El Salvador }\end{array}$ & 24.0 & 4.0 & 2.6 & 22.7 & 23.3 & -0.6 & 25.3 & 24.4 & 0.9 \\
\hline Madras, India & 28.5 & 8.0 & 6.5 & 25.2 & 24.4 & 0.8 & 31.8 & 30.6 & 1.2 \\
\hline Lagos, Nigeria & 28.4 & 3.4 & 1.7 & 27.5 & 27.2 & 0.3 & 29.3 & 25.8 & 3.4 \\
\hline Belem, Brasil & 26.9 & 2.2 & 0.4 & 27.3 & 27.2 & 0.0 & 26.5 & 27.8 & -1.2 \\
\hline Matadi, Congo & 25.3 & 3.8 & 2.1 & 26.4 & 28.6 & -2.2 & 24.2 & 24.2 & 0.0 \\
\hline Jakarta, Indonesia & 28.1 & 3.1 & 1.5 & 28.9 & 26.7 & 2.2 & 27.3 & 27.2 & 0.1 \\
\hline $\begin{array}{l}\text { Dar Es Salaam, } \\
\text { Tanzania }\end{array}$ & 27.3 & 3.9 & 2.3 & 28.4 & 27.8 & 0.7 & 26.2 & 23.9 & 2.3 \\
\hline Lusaka, Zambia & 19.9 & 7.5 & 6.1 & 23.0 & 22.8 & 0.2 & 16.8 & 16.7 & 0.2 \\
\hline Broome, Australia & 26.5 & 9.4 & 8.1 & 30.6 & 30.0 & 0.6 & 22.4 & 21.1 & 1.3 \\
\hline Pt. Hedland, Australia & 26.2 & 10.8 & 9.5 & 31.0 & 29.4 & 1.5 & 21.4 & 20.6 & 0.9 \\
\hline Antofagasta, Chile & 16.7 & 7.3 & 6.1 & 19.8 & 20.6 & -0.8 & 13.6 & 14.4 & -0.8 \\
\hline Alice Springs, Australia & 21.3 & 11.3 & 10.1 & 26.4 & 26.7 & -0.3 & 16.2 & 13.9 & 2.3 \\
\hline Asunction, Paraguay & 23.2 & 10.7 & 9.6 & 28.0 & 27.8 & 0.2 & 18.4 & 18.3 & 0.1 \\
\hline Geraldton, Australia & 20.3 & 10.6 & 9.6 & 25.1 & 24.2 & 0.9 & 15.5 & 15.6 & -0.1 \\
\hline Durban, S. Africa & 21.1 & 9.9 & 9.0 & 25.6 & 24.4 & 1.1 & 16.6 & 17.8 & -1.2 \\
\hline Perth, Australia & 19.1 & 10.5 & 9.6 & 23.9 & 24.4 & -0.6 & 14.3 & 13.3 & 1.0 \\
\hline Santiago, Chile & 13.9 & 12.6 & 11.7 & 19.7 & 21.1 & -1.4 & 8.1 & 8.3 & -0.3 \\
\hline Sydney, Australia & 19.1 & 10.9 & 10.1 & 24.1 & 22.8 & 1.4 & 14.1 & 12.2 & 1.8 \\
\hline Cape Town, S. Africa & 16.7 & 10.3 & 9.5 & 21.4 & 21.1 & 0.3 & 12.0 & 12.8 & -0.8 \\
\hline Mildura, Australia & 14.9 & 12.8 & 11.9 & 20.9 & 24.2 & -3.3 & 8.9 & 9.7 & -0.8 \\
\hline $\begin{array}{l}\text { San Rafael, } \\
\text { Argentina }\end{array}$ & 15.1 & 16.1 & 15.2 & 22.7 & 23.9 & -1.2 & 7.5 & 8.3 & -0.9 \\
\hline Buenos Aires, Argentina & 17.3 & 11.9 & 11.0 & 22.8 & 23.9 & -1.1 & 11.8 & 10.0 & 1.8 \\
\hline Wagga Wagga, Australia & 15.0 & 15.2 & 14.3 & 22.2 & 23.1 & -0.9 & 7.8 & 7.5 & 0.3 \\
\hline Mt Gambier, Australia & 14.1 & 9.2 & 8.4 & 18.3 & 17.8 & 0.5 & 9.9 & 9.4 & 0.5 \\
\hline
\end{tabular}

least for places where the seasonal cycle is symmetric, i.e. where the extreme temperatures occur in January and July. This is true at most places poleward of $40^{\circ}$, except for some west coast locations, which tend to lag by one or even to months (Section 2.1). 


\section{Deducing geographical information from the mean temperature and its annual range}

It is possible to guesstimate location from the combination of annual mean and annual range of screen temperatures. The procedures outlined in Section 5 and in LG02 are inverted to estimate the latitude L (degrees), elevation $\mathrm{h}(\mathrm{m})$, and distance inland $\mathrm{d}(\mathrm{km})$ from the observed mean temperature $\mathrm{T}_{\mathrm{o}}\left({ }^{\circ} \mathrm{C}\right)$ and its apparent annual range $\mathrm{R}_{\mathrm{jo}}(\mathrm{K})$. These procedures involve more input parameters than the above three key geographic determinants, so four further simplifications are required. Firstly, the third method given in LG02 is used to estimate the annual-mean temperature of a place. This method ignores variations from the zonal-mean elevation-adjusted temperature. The mean absolute error of this method is $1.5 \mathrm{~K}$ for the 46 places listed in LG02. Secondly, the difference between hemispheres is ignored in the application of this method. This increases the mean absolute error to $2.2 \mathrm{~K}$. Thus:

$\mathrm{T}_{\mathrm{o}}=27-0.0077 \mathrm{~L}^{2}-0.005 \mathrm{~h}^{\circ} \mathrm{C}$

Thirdly, the effects of seas to the north or south (M) and of any mountain barrier (B) are neglected in estimating the ATR. Fourthly average values are assumed for the coefficient and power in Eq. (5). Thus:

$\mathrm{R}_{\mathrm{jo}}=0.12 \mathrm{~L}(\mathrm{~d}+15)^{0.19} \mathrm{~K}$

The mean absolute error of Eq. (6b) it is $2.6 \mathrm{~K}$, for the 54 places listed in Table 3. Error analysis of both equations suggests that the errors for $\mathrm{T}_{\mathrm{o}}$ and $\mathrm{R}_{\mathrm{jo}}$ of $2.2 \mathrm{~K}$ and $2.6 \mathrm{~K}$, respectively, yield an uncertainty in latitude $\mathrm{L}$ of about $5^{\circ}$, and in height $\mathrm{h}$ of about $500 \mathrm{~m}$. The distance inland $\mathrm{d}$ cannot be estimated with any accuracy because its relative error is about five times that of ATR, and it is not possible to account for seasonally changing wind directions. Also, the hemisphere cannot be determined. Two equations (6a and $6 \mathrm{~b}$ ) mathematically cannot yield three variables (L, h, and d) without additional constraints. The values of $\mathrm{L}, \mathrm{h}$ and $\mathrm{d}$ are constrained to be realistic: $0<\mathrm{L}<60^{\circ}, 0<\mathrm{d}<14,000 \mathrm{~km}$, and $0<\mathrm{h}<6,000 \mathrm{~m}$. A variational technique is used: the absolute difference in L, as derived from Eqs. (6a) and (6b) respectively, is minimized for all possible values of $d$ and $h$. If multiple combinations of $\mathrm{d}$ and $\mathrm{h}$ yield the same absolute difference, then the one with the lowest elevation is chosen, because most stations are at low elevation. The selected values of $d$ and $h$ values then yield the best-guess value for $\mathrm{L}$ by means of Eq. (6). The procedure will select zero values for latitude $\mathrm{L}$ and elevation $\mathrm{h}$ for stations warmer than $27^{\circ} \mathrm{C}$, such as Madras in India, because that selection yields the best match for Eq. (6a). The distance $d$ therefore is undetermined (Eq. 6b). In other words this procedure cannot discriminate the location of hot low-latitude places. This is not surprising since the ATR at these places is very small (Fig. 3) and the annual-mean temperature nearly uniform (LG02).

This procedure is tested for some examples in Table 5. The main uncertainty regards Eq. (6a): a low temperature can be due either to a high latitude $o r$ to a high elevation. Equation (6b) does not influence this choice because the ATR is independent of elevation. In the case of Ulaan Baatar, the minimization technique settles with too high

Table 5. Estimation of latitude $\mathrm{L}$, distance inland $\mathrm{d}$, and elevation $\mathrm{h}$ from observed values of mean temperature $\mathrm{T}_{\mathrm{o}}$ and apparent ATR $R_{\text {jo }}$ at 8 locations. The last three columns show the departures from the actual values of $L$, $d$, and $h$ for these locations. Latitudes are positive in both hemispheres

\begin{tabular}{|c|c|c|c|c|c|c|c|c|}
\hline \multirow{2}{*}{$\begin{array}{l}\text { Location } \\
\text { (city, country) }\end{array}$} & \multicolumn{2}{|c|}{ Observed } & \multicolumn{3}{|c|}{ Estimated } & \multicolumn{3}{|c|}{ Error: [estimated - actual] } \\
\hline & $\mathrm{T}_{\mathrm{o}}:{ }^{\circ} \mathrm{C}$ & $\mathrm{R}_{\mathrm{jo}}: \mathrm{K}$ & $\mathrm{L}:^{\circ}$ & $\mathrm{d}: \mathrm{km}$ & h:m & $\mathrm{L}:^{\circ}$ & $\mathrm{d}: \mathrm{km}$ & $\mathrm{h}: \mathrm{m}$ \\
\hline Moscow, Russia & 4.4 & 26.1 & 53.0 & 6300 & 200 & -3.0 & 4500 & 10 \\
\hline Paris, France & 11.1 & 15.6 & 38.6 & 580 & 895 & -10.1 & 300 & 799 \\
\hline Ulaan Baatar, Mongolia & -0.4 & 38.9 & 56.6 & 9750 & 550 & 8.6 & 1800 & -766 \\
\hline Chicago, USA & 10.0 & 28.9 & 39.9 & 5500 & 950 & -2.1 & 2530 & 700 \\
\hline Laramie, USA & 5.0 & 23.9 & 39.8 & 4800 & 1965 & -1.5 & 3260 & -256 \\
\hline Canberra, Australia & 13.3 & 14.4 & 31.2 & 1050 & 1250 & -4.1 & 450 & 673 \\
\hline Mexico City, Mexico & 16.7 & 7.2 & 12.9 & 3290 & 1805 & -6.5 & 2980 & -429 \\
\hline Lusaka, Zambia & 21.1 & 6.8 & 9.9 & 870 & 1030 & -5.4 & -430 & -124 \\
\hline
\end{tabular}


a latitude, near sea level, while the opposite is true for Paris. The distance inland $\mathrm{d}$ is overestimated in most cases, and its value is very sensitive to the choice of power in Eq. 6b. The mean absolute errors for $\mathrm{L}, \mathrm{d}$, and $\mathrm{h}$ are $5.2^{\circ}, 2300 \mathrm{~km}$, and $470 \mathrm{~m}$, respectively, for the 8 cases listed in Table 5.

\section{Discussion}

The errors in ATR estimation are of the same magnitude as the interannual variability of ATR. That variability can be represented by the standard deviation of ATR values over 30 years, say. The standard deviation of ATR for the NNGR grid boxes in which the 50 places listed in Table 3 range from $0.2 \mathrm{~K}$ to $3.8 \mathrm{~K}$, over the period 1968-1996. The estimation errors of ATR (Section 5) and of January and July mean temperatures (Section 6) are within the scope of such variability.

There are some similarities, and some differences, in the geographic factors influencing the annual-mean temperature (LG02) and its annual range. Latitude is the primary factor for both. The second key factor affecting the annual mean is elevation, which does not directly affect the ATR. Instead the ATR is strongly dependent on inland fetch. Upwind distance from the sea (in any direction) is of little significance to the annual mean. Some similarity exists again at the third level: a zonal variation of mean temperature occurs across many continents, especially if a mountain range occurs near the west coast; and the ATR increases rapidly across a mountain range blocking the airflow. The effects of inland seas, land use, and local shape of terrain, on either annual mean or ATR, are ignored in these studies. These small-scale effects, especially the terrain shape, influence the ATR more strongly than the annual mean. It is not surprising, then, that the estimation error for the ATR $(1.0 \mathrm{~K}$, Section 5) is larger than that for the annual mean $(0.7 \mathrm{~K}, \mathrm{LG} 02)$.

It is noteworthy that the belt of maximum ATR at a given latitude, in the lee of a mountain range, sometimes coincides with the belt of highest annual-mean temperature (the 'thermal ridge', LG02), for instance in South America $\left(10-40^{\circ} \mathrm{S}\right)$. More generally, as in North America, the thermal ridge is to the west of the belt of maximum ATR.
The main weakness of the ATR estimation method presented herein is the assumption that the on-land fetch can be approximated by the distance to the coast in a zonal direction, rather than in the actual direction of the prevailing wind. This assumption loses validity in the pcoximity of an ocean to the south or north. The introduction of the meridional ocean factor M (Section 3.4) attempts to compensate for this weakness. ATR errors as large as $6 \mathrm{~K}$ result without this correction (Fig. 12). It is not clear why this factor is needed in some cases, as in North America, and not in others, as in Australia and other low-latitude regions. One possibility is that at higher latitudes an ocean to the north or south is felt through transient meridional winds (a characteristic of midlatitude frontal systems) even when the prevailing wind is westerly. These transient winds presumably adjust to the underlying surface over the width of the belt where $M$ is significant (400-800 km).

Finally, the empirical nature of this study is emphasised. The next step is to physically interpret the empirical relationships presented here and in LG02 by means of atmospheric circulation models, using both idealised and actual outlines of continents and mountains. In particular there is the intriguing dependence of the ATR on fetch to the power of 0.2 .

\section{Conclusions}

- The annual range of screen-level air temperatures (ATR) is larger over extratropical continents than over adjacent oceans. The ATR over land increases approximately linearly with latitude, at $0.3-0.5 \mathrm{~K} /{ }^{\circ}$.

- The ATR increases with the distance downwind of an ocean, but the relative change of ATR is only one fifth of that of distance. The ATR depends on the direction of the prevailing winds, but not on their speed. For an approximate estimate of the ATR, only the zonal wind direction is considered, though a correction for proximity to an ocean to the north or south is preferably included.

- The ATR is affected by topography in three different ways: it increases rapidly across any large mountain chain that blocks the prevailing wind, especially if the ridge is near the 
coast; it is larger in valleys than on ridges; and it decreases slightly with elevation $(1-2 \mathrm{~K} / \mathrm{km})$. These effects are proportional to latitude.

- The ATR is affected by the presence of inland seas and large lakes, and the influence increases with the sea's size.

- A first-order estimation of ATR is based primarily on latitude and zonal distance inland, with adjustments for blocking mountains and the proximity of an ocean to the north or south. Its application to 50 independently selected places yields an mean absolute error of $1.0 \mathrm{~K}$ and a bias of $0.3 \mathrm{~K}$.

- The estimates of the annual-mean temperature (LG02) and the ATR can be combined to obtain temperatures for July and January for any location, with a mean absolute error of $1.0 \mathrm{~K}$.

- Latitude, distance inland and elevation can be roughly deduced from the combination of observed annual mean and range of temperatures. The underlying empirical relationships represent an advance on the merely qualitative generalisations customary in education, and lend themselves readily to software applications.

\section{Acknowledgments}

Thanks are due to Edward Linacre (Australian National University) for instigating this work and for his critical reviews. Figure 3 was reprinted with permission of Academic Press. Figure 18 was provided by Peter Jones (Centro Internacional de Agricultura Tropical in Columbia). Some data for Figure 6 were provided by Colin Banfield (University of Newfoundland), Gerald Mills (University College, Dublin), Michael Harrison (University of Southern Mississippi) and Greg Carbone (University of South Carolina).

\section{References}

Andreasson FP, Schmitz B (1996) Winter and summer temperatures of the early middle Eocene of France from Turritella delta ${ }^{18} \mathrm{O}$ profiles. Geology 24: 1067-1070

— , - (2000) Temperature seasonality in the early middle Eocene North Atlantic region; evidence from stable isotope profiles of marine gastropod shells. Bull Geol Soc Amer 112: 628-640

Barry RG, Chorley RJ (1998) Atmosphere, weather and climate. 7th edn. $\mathbf{\square}$ : Routledge; 409 pp
Cathey HM (1990) The USDA Plant Hardiness Map of North America. USDA Misc. Publ. No. 1475. [available from: U.S. National Arboretum, Agricultural Research Service, U.S. Department of Agriculture, Washington, DC 20002]

Conrad V (1940) Investigations into periodicity of the annual range of air temperature. The Pennsylvania State College Bulletin 36(59): 23 pp

Geerts B (2002a) On the effects of irrigation and urbanisation on the annual range of monthly mean temperatures. Theor Appl Climat (in press)

Geerts B (2002b) Estimating the daily range of temperatures empirically. Theor Appl Climat (submitted)

Geiger R (1965) The climate near the ground. Cambridge: Harvard University Press: $611 \mathrm{pp}$

Hess M (1968a) A method of distinguishing and specifying vertical climatic zones in temperate zone mountains. Geog Polonica 14: 133-40

Jones DA (1999) Characteristics of Australian land surface temperature variability. Theor Appl Climat 63: 11-31

Kalnay E, Kanamitsu M, Kistler R, Collins W, Deaven D, Gandin L, Iredell M, Saha S, White G, Woollen J, Zhu Y, Chelliah M, Ebisuzaki W, Higgins W, Janowiak J, Mo KC, Ropelewski C, Wang J, Leetmaa A, Reynolds R, Jenne R, Joseph D (1996) The NCEP/NCAR 40-Year Reanalysis Project. Bull Amer Meteor Soc 77: 437-72

Konrad CE (1998) Intramonthly indices of the Pacific/ North American teleconnection pattern and temperature regimes over the United States. Theor Appl Climat 60: 11-19

Legates DR, Willmott CJ (1990) Mean seasonal and spatial variability global surface air temperature. Theor Appl Climat 41: 11-21

Linacre ET (1969) Empirical relationships involving the global radiation intensity and ambient temperature at various latitudes and altitudes. Arch Meteor Geophys Biokl B12: 1-20

- (1992) Climate data and resources. $\mathbf{\square}$ : Routledge, $366 \mathrm{pp}$.

—, Geerts B (1997) Climate and weather explained. Routledge, $432 \mathrm{pp}$

—, - (2002) Estimating the annual mean screen temperature empirically. Theor Appl Climat 71: 43-61

Martner BE (1986) Wyoming climate atlas. $\mathbf{\square}$ : University of Nebraska Press, 432 pp.

Mearns F, Giorgi, McDaniel L, Shields C (1995) Analysis of variability and diurnal range of daily temperature in a nested regional climate model: comparison with observations and doubled $\mathrm{CO}_{2}$ results. Climate Dynamics 11: 193-209

Pearce EA, Smith CG (1990) The world weather guide. Hutchinson, 480 pp.

Petersen WA, Rutledge SA (2001) Regional variability in tropical convection: observations from TRMM. J Climate (in press)

Renssen H, Isarin RFB (1997) Surface temperature in NW Europe during the Younger Dryas: AGCM simulation compared with temperature reconstructions. Climate Dynamics 14: 33-44 
Reynolds RW, Smith TM (1995) A high-resolution global sea surface temperature climatology. J Climate 8: $1571-1583$

Stafford JM, Wendler G, Curtis J (2000) Temperature and precipitation of Alaska: 50 year trend analysis. Theor Appl Climat 67: 33-44

Sverdrup HU, Johnson MW, Fleming RH (1946) The oceans, their physics, chemistry, and general biology 2nd edn. $\square$ : Prentice-Hall, 429 pp

Wallace JM, Hobbs PV (1977) Atmospheric science: an introductory survey. $\square$ : Academic Press, 467 pp
Watterson IG, (1997) The diurnal cycle of surface air temperature in simulated present and doubled $\mathrm{CO}_{2}$ climates. Climate Dynamics 13: 533-545

Zhang T, Osterkamp TE, Stamnes K (1996) Some characteristics of the climate in northern Alaska, USA. Arctic Alpine Res 28: 509-518

Author's address: Bart Geerts, Department of Atmospheric Sciences, University of Wyoming, PO Box 3038, Laramie, WY 82071-3038, USA. e-mail: geerts@ uwyo.edu 
Dear Author,

The goal of our new, more rapid publication procedures is to publish your paper online as quickly as possible. The assigning of a DOI (digital object identifier) at this stage means that the work is fully citeable much earlier than has previously been the case. Please note that final pagination will be added only when articles have been assigned to a printed issue. With respect to the quality of figures in the electronic version, please note that the printed version will be of the usual high quality. For a list of all papers published online so far, please refer to the following web-site (your paper will be added to this list after final correction):

http://link.springer.de/link/service/journals/00704/tocs.htm 


\section{Offprint Order}

Journal: Theoretical and Applied Climatology MS No.: 0/688

First Author: B. Geerts

We will supply the corresponding author with one free copy of the relevant issue.

The order of offprints against payment must be sent in when returning the corrected proofs.

The prices quoted are valid only for authors ordering offprints for their private use.

Please write clearly in capital letters!

III

When you order offprints against payment, you are entitled to receive in addition a pdf file of your article for your own personal use. As this pdf file is sent to you by e-mail, please insert the e-mail address here:

I hereby order against payment
$\square 50$
$\square 100$
200
$\square 300$
$\square 400$
offprints

Offprints should be sent to:

(Name of person or institution)

(Address)

Payment will be made by:

(Name of person or institution)

(Address)

(Purchase Order No.)

(Date/Signature of author)

Please bill me (please do not pay for offprints before receipt of invoice!)

$\square$ Eurocard / Mastercard

$\square$ American Express

$\square$ Visa

$\square$ Diners Club

No.:

$1+1$

1

1

$+|+|+\mid$

Valid until:

Signature:

(In all separate correspondence concerning this order please quote the Journal's title, MS No., and First Author.)

Price list for offprints*

Prices include carriage charges (surface mail). Prices are subject to change without notice.

*Customers in foreign EU countries: Please state your V.A.T. registration number if applicable. Otherwise we have to add $10 \%$ V.A.T. to the list prices.

V.A.T. registration number:

\begin{tabular}{|c|c|c|c|c|c|}
\hline $\begin{array}{c}\text { Pages } \\
\text { (Figs. incl./excl.) }\end{array}$ & 50 Copies & 100 Copies & 200 Copies & 300 Copies & 400 Copies \\
\hline & EUR & EUR & EUR & EUR & EUR \\
\hline$\square \quad 1-8$ & 296,-- & $348,-$ & $482,-$ & $598,-$ & $722,-$ \\
\hline$\square \quad 9-16$ & $384,-$ & $436,-$ & 626,- & $806,-$ & $998,-$ \\
\hline$\square$ 17-24 & $462,-$ & $512,-$ & $742,-$ & $972,-$ & $1198,-$ \\
\hline$\square$ 25-32 & $512,-$ & $564,-$ & $844,-$ & $1098,-$ & $1408,-$ \\
\hline
\end{tabular}

\section{Copyright Transfer Statement}

The copyright to this article is hereby transferred to Springer-Verlag (for US Government employees: to the extent transferable), effective if and when the article is accepted for publication. The copyright transfer covers the exclusive rights to reproduce and distribute the article, including reprints, photographic reproductions, microform, electronic database, videodiscs, or any other reproductions of similar nature, and translations.

However, the authors reserve:

1. All proprietary rights other than copyrights, such as patent rights.

2. The right to use all or part of this article in future works of their own and to grant or refuse permission to third parties to republish all or part of the article or translations thereof. To republish whole articles, such third parties must obtain written permission from Springer-Verlag as well. However, Springer-Verlag may grant rights concerning journal issues as a whole. 


\begin{tabular}{|c|c|c|c|}
\hline \multirow{2}{*}{ Instruction to printer } & \multirow{2}{*}{ Mark } & \multicolumn{2}{|c|}{ Examples } \\
\hline & & In the text & In the margin \\
\hline Character to be corrected & 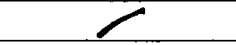 & Litter to be corrected & el \\
\hline $\begin{array}{l}\text { Group of characters to be } \\
\text { corrected }\end{array}$ & $H$ & Letters to be correcting & ed $H$ \\
\hline $\begin{array}{l}\text { Several identical characters to } \\
\text { be corrected }\end{array}$ & I & Cffuncil far C/mmission & \\
\hline $\begin{array}{l}\text { Differentiation of several errors } \\
\text { in the same paragraph }\end{array}$ & IrF L J & $\begin{array}{l}\text { Thefe are rany fof ultis } \\
\text { in thats lane }\end{array}$ & $r / L_{i}^{m}$ \\
\hline $\begin{array}{l}\text { Character or word to be } \\
\text { deleted }\end{array}$ & or & $\begin{array}{l}\text { Commissifon and } \\
\text { pad Parliament }\end{array}$ & wy \\
\hline Character or word to be added & $\alpha$ & A word/missing & is \\
\hline Superior character required & $\Lambda$ & The Court's judgment. $f$ & \\
\hline $\begin{array}{l}\text { Omitted text to be added } \\
\text { (see copy) }\end{array}$ & $\lambda$ & $\begin{array}{l}\text { 1. January } \\
\text { 12. December }\end{array}$ & \\
\hline Inferior character required & $v$ & $\mathrm{H}_{2} \mathrm{SO} /$ & 4 \\
\hline Change to italic & $=$ & Ad infinitum & $\sqrt{2}$ \\
\hline $\begin{array}{l}\text { Change italic characters } \\
\text { to roman }\end{array}$ & $\infty$ & status quo & \\
\hline Change capitals to lower case & $S$ & (NESCO) & \\
\hline $\begin{array}{l}\text { Change to capitals or small } \\
\text { capitals }\end{array}$ & $\equiv=$ & Robert burns, AD 1759-96 & (caps. \\
\hline Change to bold face & nanur & $\begin{array}{l}\text { This word needs } \\
\text { emphasising! }\end{array}$ & \\
\hline To be letter-spaced & Iगात & 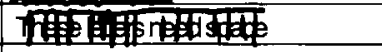 & $\pi$ \\
\hline Correct horizontal alignment & & This line is crooked & $\underline{\underline{z}}$ \\
\hline Text to be raised or lowered & $\Omega \tau r$ & $\begin{array}{l}\text { IThis } \sqrt{\text { is }} \\
\text { Jiner uneven }\end{array}$ & $\Omega /$ \\
\hline Text to be aligned (to the left) & 5 & $\begin{array}{l}\text { This text is } \\
\text { to be aligned }\end{array}$ & \\
\hline Text to be aligned (to the right) & 5 & $\begin{array}{l}\text { Fis text is } \\
\text { to be aligned }\end{array}$ & \\
\hline Text to be centred & {$[\quad]$} & $\begin{array}{l}\text { [This text is } \\
\text { to be centred] }\end{array}$ & {[} \\
\hline Take back to previous line & ] & $\begin{array}{l}\text { This hyph- } \\
\text { en is unnecessary }\end{array}$ & \\
\hline $\begin{array}{l}\text { Text to run on (no new } \\
\text { paragraph) }\end{array}$ & 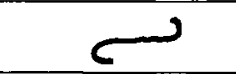 & … line. & \\
\hline Take forward to next line & {[} & $\begin{array}{l}\text { This hy } 5- \\
\text { hen is todly placed }\end{array}$ & {[} \\
\hline Create new paragraph & $\Gamma$ & $\begin{array}{l}\text {... line. } \sqrt{A} \text { new paragraph } \\
\text { should begin here }\end{array}$ & $\Gamma /$ \\
\hline Close up & $\hat{\imath}$ & $\begin{array}{l}\text { A sp ace is wrong } \\
\text { here }\end{array}$ & $\hat{n} /$ \\
\hline Equalise space & 1 & $\begin{array}{l}\text { This/spacing/is } \\
\text { very/uneven }\end{array}$ & L1 \\
\hline Add space between words & $z$ & $\begin{array}{l}\text { A spaç̄s missing } \\
\text { here }\end{array}$ & $2 \# /$ \\
\hline Reduce space between words & 2 & $\begin{array}{l}\text { These spaces are } \\
\text { too? big! }\end{array}$ & $2 /$ \\
\hline Add space between lines & $\longrightarrow \#$ & $\begin{array}{l}\text { Theselines are too }<\# \\
\text { close together }\end{array}$ & $\longrightarrow$ \\
\hline Reduce space between lines & $\rightarrow$ & $\begin{array}{l}\text { These lines are too } \\
\text { far apart. }\end{array}$ & $\rightarrow 1$ \\
\hline Stet (let original text stand) & $\ldots \ldots$ & $\begin{array}{l}\text { This text was } \\
\text { corrected Wherror }\end{array}$ & $\theta$ \\
\hline Transpose characters & $n$ & These letters are transpos $\mathbf{0}$ & n I \\
\hline Transpose words & 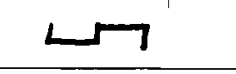 & $\begin{array}{l}\text { Theselare[woras] } \\
\text { transposed }\end{array}$ & $n /$ \\
\hline Transpose lines & $\bar{E}$ & $\begin{array}{l}\text { transposed } \\
\text { Itheselines are }\end{array}$ & $E /$ \\
\hline
\end{tabular}


As a Springer-author you are now entitled to receive a 33,3\% price reduction on the list price of all books published by Springer-Verlage Wien, Berlin/Heidelberg, New York, London, Paris, Barcelona, Tokyo and Hong Kong as well as Böhlau/Wien, Physica, Birkhäuser und Steinkopff. For your order please use this order form. Orders have to be sent directly to Springer-Verlag Vienna.

Als Autor/in des Springer-Verlages erhalten Sie 33,3 \% Rabatt auf den Ladenpreis der gesamten Buchproduktion der Springer-Verlage Wien, Berlin/Heidelberg, New York, London, Paris, Barcelona, Tokyo und Hong Kong sowie der angeschlossenen Verlage Böhlau/Wien, Physica, Birkhäuser und Steinkopff. Bitte bestellen Sie mit diesem Bestellschein. Ihre Bestellung senden Sie bitte ausschließlich an den Springer-Verlag Wien.

For detailed information about titles published by Springer-Verlag please search our homepage. Nähere Informationen über das Programm des Springer-Verlages finden Sie auf unserer Homepage. http://www.springer.at

\section{Order Form / Bestellschein}

Springer-Verlag, Order Department, Sachsenplatz 4-6, P.O. Box 89, A-1201 Vienna, Fax +43.1.330 2426

Springer-Verlag, Auslieferung, Sachsenplatz 4-6, Postfach 89, A-1201 Wien, Fax +43.1.330 2426

I order herewith / Ich bestelle hiermit:

$\begin{array}{llll}\text { copy/ies } & \text { ISBN } & \text { Author } & \text { Title } \\ \text { Expl. } & \text { ISBN } & \text { Autor } & \text { Titel }\end{array}$

o Please bill me / Bitte liefern Sie gegen Rechnung

o Please charge my credit card / Bitte belasten Sie meine Kreditkarte
O VISA
O MASTERCARD
O AMEX
O DINERS

Card No. / Karten-Nr.

Expiry date / Gültig bis

NAME / NAME

ADDRESS / ADRESSE

DATE / DATUM 